\title{
A review of microscopy-based evidence for the association of Propionibacterium acnes biofilms in degenerative disc disease and other diseased human tissue
}

\author{
Manu N. Capoor ${ }^{1,5}$ (1) $\cdot$ Christof Birkenmaier ${ }^{2}$. Jeffrey C. Wang ${ }^{3} \cdot$ Andrew McDowell $^{4} \cdot$ Fahad S. Ahmed ${ }^{5}$. \\ Holger Brüggemann ${ }^{6} \cdot$ Erin Coscia $^{7} \cdot$ David G. Davies $^{8} \cdot$ Soren Ohrt-Nissen $^{9} \cdot$ Assaf Raz $^{1} \cdot$ Filip Ruzicka $^{10}$. \\ Jonathan E. Schmitz ${ }^{11}$ • Vincent A. Fischetti ${ }^{1}$. Ondrej Slaby ${ }^{5}$
}

Received: 26 February 2019 / Revised: 18 July 2019 / Accepted: 20 July 2019 / Published online: 29 July 2019

(c) The Author(s) 2019

\begin{abstract}
Purpose Recent research shows an increasing recognition that organisms not traditionally considered infectious in nature contribute to disease processes. Propionibacterium acnes (P. acnes) is a gram-positive, aerotolerant anaerobe prevalent in the sebaceous gland-rich areas of the human skin. A ubiquitous slow-growing organism with the capacity to form biofilm, $P$. acnes, recognized for its role in acne vulgaris and medical device-related infections, is now also linked to a number of other human diseases. While bacterial culture and molecular techniques are used to investigate the involvement of $P$. acnes in such diseases, definitive demonstration of $P$. acnes infection requires a technique (or techniques) sensitive to the presence of biofilms and insensitive to the presence of potential contamination. Fortunately, there are imaging techniques meeting these criteria, in particular, fluorescence in situ hybridization and immunofluorescence coupled with confocal laser scanning microscopy, as well as immunohistochemistry.

Methods Our literature review considers a range of microscopy-based studies that provides definitive evidence of $P$. acnes colonization within tissue from a number of human diseases (acne vulgaris, degenerative disc and prostate disease and atherosclerosis), some of which are currently not considered to have an infectious etiology.

Results/Conclusion We conclude that $P$. acnes is an opportunistic pathogen with a likely underestimated role in the development of various human diseases associated with significant morbidity and, in some cases, mortality. As such, these findings offer the potential for new studies aimed at understanding the pathological mechanisms driving the observed disease associations, as well as novel diagnostic strategies and treatment strategies, particularly for degenerative disc disease.
\end{abstract}

\section{Graphic abstract}

These slides can be retrieved under Electronic Supplementary Material.
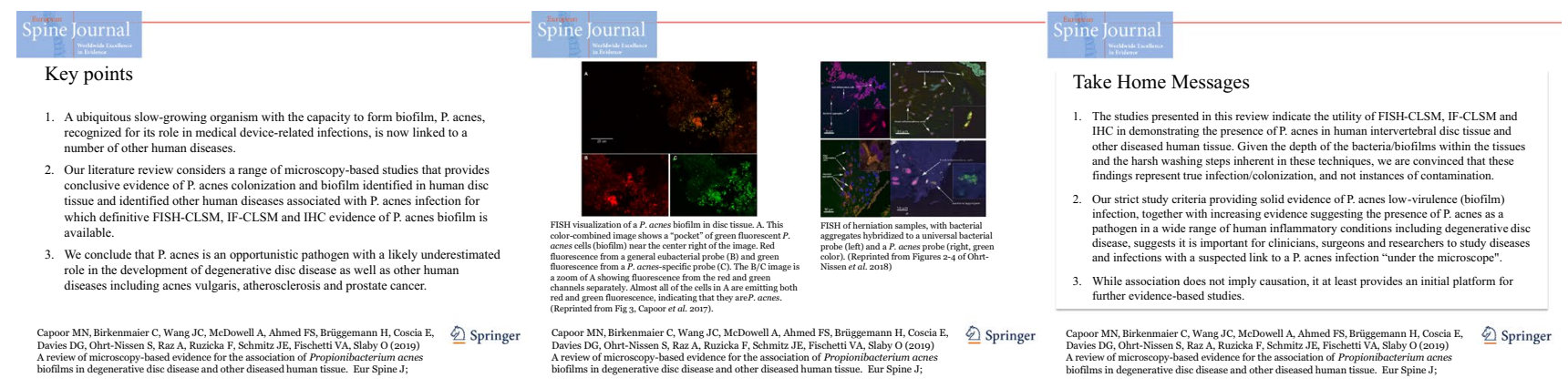

Electronic supplementary material The online version of this article (https://doi.org/10.1007/s00586-019-06086-y) contains supplementary material, which is available to authorized users.

Extended author information available on the last page of the article 
Keywords Acne vulgaris · Arthroscopy $\cdot$ Atherosclerosis $\cdot$ Biofilm $\cdot$ Cutibacterium acnes $\cdot$ Degenerative disc disease $\cdot$ FISH-CLSM $\cdot$ Propionibacterium acnes $\cdot$ Prostate cancer

\section{Introduction}

In recent years, our understanding of the relationship between human-associated microbes and human health has undergone a profound change, with an increasing recognition that organisms not traditionally considered infectious in nature can contribute to disease processes. An organism's pathogenic role can entail complex interactions with not only the host, but also the environment and other members of the human microbiome. This "pathobiome" model of disease challenges long-held notions of what defines a pathogen, obfuscates the classic metric of Koch's postulates and raises entirely new questions about how microbe-associated conditions can be diagnosed and managed [1]. Falling into this exciting (but challenging) paradigm is the hypothesis that Propionibacterium acnes (P. acnes) can contribute to the etiology of various human disease states.

Propionibacterium acnes is a Gram-positive, aerotolerant anaerobe that forms part of the microbiota of the human skin $[2,3]$ as well as the oral cavity, large intestine and urinary tract [4]. It grows slowly under anaerobic conditions and has the capacity to produce biofilms in vitro and in vivo $[4,5]$. $P$. acnes is routinely isolated from all patient specimen types submitted to the clinical laboratory except urine; its absence from urine cultures may reflect an inadequate incubation period [6]. Although $P$. acnes is a commensal organism important for skin health, it is also an opportunistic pathogen and the single dominant bacterium associated with the inflammatory skin condition acne after which it was named ${ }^{6}$. Its association with infections and clinical conditions beyond the skin has become increasingly recognized, particularly in relation to postoperative device-related infections [7], including those associated with prosthetic shoulder joints [8] and cerebrovascular [9], breast [10], spine [11] and cardiovascular device implants [12]. While a role for P. acnes biofilms in the pathogenesis of medical-device-related infections is now generally accepted [5, 13], there is also increasing evidence that the bacterium may act as an endogenous pathogen in a range of other human inflammatory conditions, particularly degenerative disc disease (DDD), raising the prospect of new diagnostic and therapeutic opportunities, including vaccination [14].

Recognition that $P$. acnes is associated with an increasing number of human conditions has always been tempered by the justified concern of contamination. Since P. acnes is part of the normal human microbiota, differentiation of true infection from contamination of biopsy samples can be a significant problem. As with other human commensals, Koch's original postulates cannot be truly satisfied in relation to the establishment of a causal effect in disease. Therefore, other approaches must be pursued to establish a link or association. Conventional bacterial culture of potentially infected and negative control tissues is susceptible to falsepositive results because it is sensitive to low-level bacterial contamination from the surgical environment, the clinical laboratory or the patient's skin. It is also susceptible to falsenegative results due to the presence of the biofilm matrix, which requires a rigorous disassembly step, such as tissue homogenization (when biofilm resides deep within tissue) [15] or sonication (when the biofilm resides on surface of the implant) [16] to enhance detection sensitivity, as well as its slow growth, which requires prolonged cultivation (for up to 14 days) [17]. Culture-independent molecular techniques for detecting $P$. acnes (e.g., direct tissue PCR) suffer from these same inherent limitations $[15,18]$.

As a result of these issues, conclusive demonstration of $P$. acnes infection or colonization requires a sensitive diagnostic technique, or series of techniques, that are conducive to the detection of true infection while eliminating the presence of contamination. Fortunately, imaging techniques such as fluorescence in situ hybridization coupled with confocal laser scanning microscopy (FISH-CLSM), immunofluorescence-CLSM (IF-CLSM) and immunohistochemistry (IHC) help fulfill these criteria by providing robust methods to visually identify biofilms that are insensitive to contaminating bacterial cells. The methods also provide definitive locations and morphologies of any P. acnes present. Bacteria with biofilm-like morphologies found deep within infected tissues cannot reasonably result from contamination since no time would be available for such matrix structures to form after surgical removal and immediate processing, or subsequent freezing pending analysis. Furthermore, and importantly, FISH-CLSM, IF-CLSM and IHC methods can also reduce or eliminate superficial contamination because sample preparation involves multiple harsh wash steps.

In preparation for this review, we surveyed the literature to identify human diseases associated with $P$. acnes infection, but for which definitive FISH-CLSM, IF-CLSM and IHC evidence of $P$. acnes biofilm within potentially infected human tissue from these conditions is available. In the following sections, we describe the current state-ofknowledge on the relationship between $P$. acnes and various diseases, including some not traditionally considered infectious in nature. These descriptions will include the underlying experimental methodologies used to generate the data. Although association does not indicate causation without further investigations, it does highlight how subtle hostmicrobe interactions with the pro-inflammatory $P$. acnes 
bacterium may be driving the pathogenesis of a number of diverse human diseases.

\section{Study selection}

Initial searches queried the PubMed database for original research articles published between September 17th, 1997 and August 30th, 2018. Articles published in any language were retrieved using the keyword Propionibacterium acnes AND/OR acne vulgaris, atherosclerosis, degenerative disc disease (DDD), prostate cancer, prostate hyperplasia, biofilm, infection, sarcoidosis and microscopy. A substantial proportion of the research articles initially retrieved using our search criteria were subsequently excluded (in vitro, cell lines, biology, genetics, genomics, animal models, treatment, reviews, commentaries, letters) because they did not describe studies of patients.

These initial searches yielded 2376 articles; 2033 of which were excluded using the search criteria described above. The remaining 343 original research articles were fully reviewed to identify the diagnostic methods utilized to detect the presence of $P$. acnes in human tissue. Of the 343 original research articles, 204 comprised retrospective or prospective studies and 139 were case studies (see Fig. 1).

The 204 remaining original articles where the tissue was assessed for the presence of $P$. acnes (case studies were excluded) were categorized into four groups: first-time original procedures utilizing tissue samples $(n=96)$, revision procedures with implant devices $(n=60)$, revision procedures involving tissues samples $(n=20)$ and samples from superficial swabs or surgical site infections $(n=28)$.

From the 204 original research articles and our exclusion and inclusion criteria, we identified 21 studies presenting microscopy-based evidence (e.g., FISH-CLSM, IF-CLSM and IHC with $P$. acnes-specific FISH probes or antibodies) for a clear role in human disease. These studies are presented in Table 1.

\section{Review of $P$. acnes biofilm infections in human disease}

After carefully evaluating the studies presented in Table 1, and applying our strict inclusion and exclusion criteria, 10 studies remained that showed relevant microscopic findings (i.e., FISH-CLSM, IF-CLSM and IHC) regarding $P$.

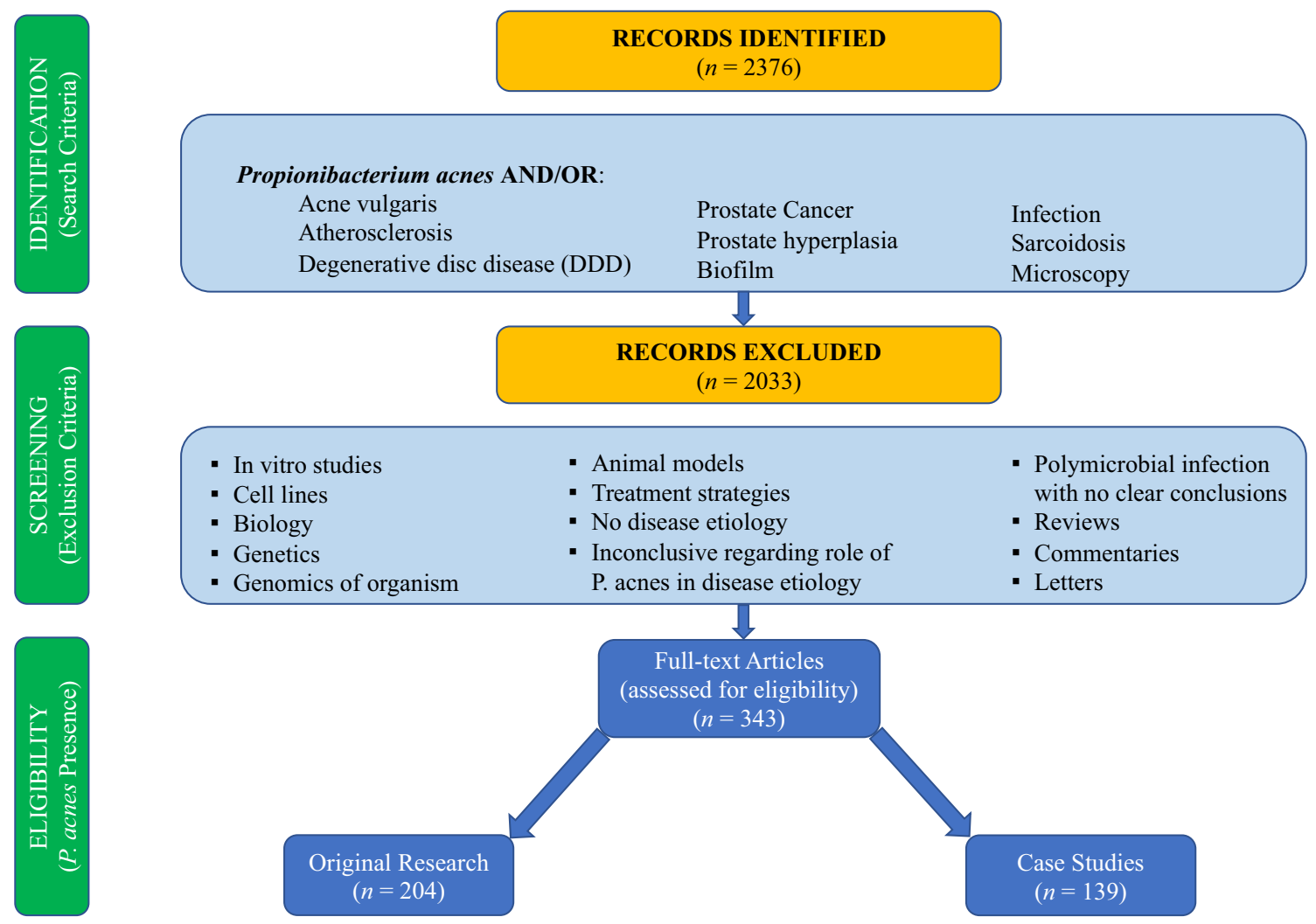

Fig. 1 Search criteria identified original research articles (September 17th, 1997 to August 30th, 2018) where tissue was assessed for the presence of P. acnes 


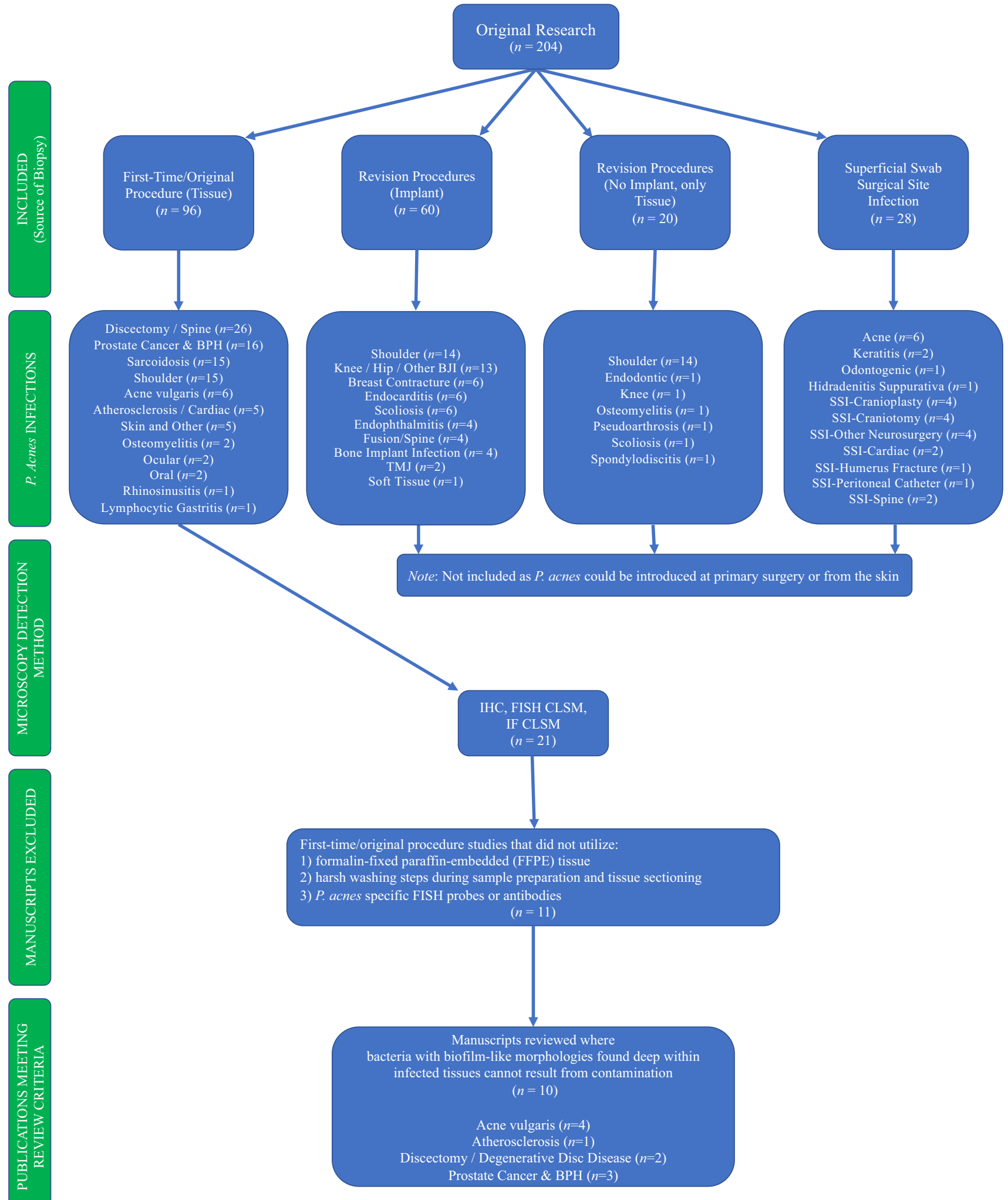

Fig. 2 Search results identified original research articles (September 17th, 1997 to August 30th, 2018) where tissue was assessed for the presence of P. acnes 
Table 1 Review of original research articles (9/17/97-8/30/18) where tissue was assessed utilizing FISH-CLSM, IF-CLSM and/or IHC

\begin{tabular}{|c|c|c|c|c|c|c|c|c|}
\hline \multicolumn{2}{|l|}{ Study particulars } & \multicolumn{2}{|l|}{ Study design } & \multirow{2}{*}{$\begin{array}{l}\text { P. acnes identified } \\
\text { Condition/proce- } \\
\text { dure }\end{array}$} & \multicolumn{3}{|c|}{ Diagnostic microscopy } & \multirow{2}{*}{$\begin{array}{l}\text { Inclusion criteria } \\
\text { 1. FFPE or cryopre- } \\
\text { served } \\
\text { 2. Harsh washing } \\
\text { 3. Tissue sectioning } \\
\text { 4. Specific probe }\end{array}$} \\
\hline Publication date & References & Patient cases & $\begin{array}{l}\text { Prospective } \\
\text { Retrospective }\end{array}$ & & IHC & FISH-CLSM & IF-CLSM & \\
\hline $02 / 22 / 12$ & Jahns et al. [19] & 38 & Prospective & Acne vulgaris & & & $\bullet$ & Included \\
\hline $04 / 19 / 12$ & Alexeyev et al. [20] & 38 & Retrospective & Acne vulgaris & $\bullet$ & $\bullet$ & $\bullet$ & Included \\
\hline $07 / 27 / 13$ & Jahns et al. [21] & 8 & Retrospective & Acne vulgaris & & $\bullet$ & $\bullet$ & Included \\
\hline $12 / 11 / 14$ & Jahns et al. [22] & 143 & Prospective & Acne vulgaris & $\bullet$ & & $\bullet$ & Included \\
\hline $07 / 27 / 15$ & Lanter et al. [23] & 30 & Prospective & $\begin{array}{l}\text { Atherosclerosis- } \\
\text { Carotid }\end{array}$ & & $\bullet$ & & Included \\
\hline $04 / 03 / 17$ & Capoor et al. [15] & 368 & Prospective & $\begin{array}{l}\text { Discectomy- } \\
\text { Lumbar }\end{array}$ & & $\bullet$ & & Included \\
\hline $04 / 27 / 18$ & $\begin{array}{l}\text { Ohrt-Nissen et al. } \\
\text { [24] }\end{array}$ & 51 & Prospective & $\begin{array}{l}\text { Discectomy- } \\
\text { Lumbar }\end{array}$ & & $\bullet$ & & Included \\
\hline $10 / 12 / 10$ & $\begin{array}{l}\text { Fassi Fehri et al. } \\
\text { [25] }\end{array}$ & 71 & Prospective & Prostate cancer & & & $\bullet$ & Included \\
\hline 01/01/17 & $\begin{array}{l}\text { Kakegawa et al. } \\
\text { [26] }\end{array}$ & 44 & Retrospective & Prostate cancer & $\bullet$ & & & Included \\
\hline 09/19/07 & Alexeyev et al. [27] & 10 & Prospective & $\begin{array}{l}\text { Prostate cancer/ } \\
\text { BPH }\end{array}$ & & $\bullet$ & & Included \\
\hline $12 / 02 / 15$ & $\begin{array}{l}\text { Jahns \& Alexeyev } \\
\text { [28] }\end{array}$ & 194 & Retrospective & Benign nevus & & & $\bullet$ & Excluded \\
\hline 08/02/05 & $\begin{array}{l}\text { McLorinan et al. } \\
\text { [29] }\end{array}$ & 79 & Prospective & $\begin{array}{l}\text { Discectomy- } \\
\text { Lumbar }\end{array}$ & & & $\bullet$ & Excluded \\
\hline $01 / 30 / 14$ & Jahns et al. [30] & 27 & Retrospective & $\begin{array}{l}\text { Hidradenitis Sup- } \\
\text { purativa }\end{array}$ & & $\bullet$ & $\bullet$ & Excluded \\
\hline $02 / 28 / 14$ & Bae et al. [31] & 46 & Retrospective & Prostate cancer & $\bullet$ & & $\bullet$ & Excluded \\
\hline 05/08/13 & Boase et al. [32] & 44 & Prospective & Rhinosinusitis & & $\bullet$ & & Excluded \\
\hline 07/07/17 & Asakawa et al. [33] & 107 & Retrospective & $\begin{array}{l}\text { Sarcoidosis- } \\
\text { Cardiac }\end{array}$ & $\bullet$ & & & Excluded \\
\hline $10 / 04 / 02$ & Yamada et al. [34] & 27 & Retrospective & $\begin{array}{l}\text { Sarcoidosis-Multi- } \\
\text { ple Sites }\end{array}$ & & $\bullet$ & & Excluded \\
\hline 02/05/18 & Suzuki et al. [35] & 128 & Retrospective & $\begin{array}{l}\text { Sarcoidosis-Multi- } \\
\text { ple Sites }\end{array}$ & $\bullet$ & & & Excluded \\
\hline 03/07/17 & Goto et al. [36] & 10 & Prospective & Sarcoidosis-Ocular & $\bullet$ & & & Excluded \\
\hline $11 / 09 / 17$ & Nagata et al. [37] & 23 & Prospective & Sarcoidosis-Ocular & $\bullet$ & & & Excluded \\
\hline 05/18/12 & Negi et al. [38] & 471 & Retrospective & $\begin{array}{l}\text { Sarcoidosis-Pulmo- } \\
\text { nary }\end{array}$ & $\bullet$ & & $\bullet$ & Excluded \\
\hline
\end{tabular}

acnes infection in acne vulgaris, DDD, prostate disease and atherosclerosis.

\section{Degenerative disc disease}

Degenerative disc disease (DDD) is a multifactorial condition that can lead to pain and often will progress to degenerative osteochondrosis and other significant spinal pathology. Age and various environmental factors are known to increase risk, but no strong correlation has been shown [39]. A multitude of studies have revealed a significant heritability for disc disease, but the mode of inheritance is multifactorial and the high number of potentially causative genes limits their clinical applicability [40]. In addition to the mechanical and genetic factors that can lead to the pathogenesis of disc degradation, several studies have found evidence of $P$. acnes present in intervertebral disc tissue which may contribute to its deterioration $[41,42]$. The majority of these studies, however, applied cultivation and/or PCR techniques, which are susceptible to the previously mentioned limitations of potential false-positive and false-negative results. A randomized controlled trial published in 2013 showed that a 90-day treatment with antibiotics significantly changed 
the clinical symptoms of DDD as well as the appearance of new Modic type-1 endplate changes when compared to placebo [43]. However, a fundamental weakness of this study is that the true presence of an infection was not investigated but implied based on the findings of another parallel study on a different group of discectomy patients. Furthermore, whether the observed difference between the antibiotic and the placebo groups could actually be attributed to the antimicrobial effects of treatment on a true disc infection or reflected a non-specific anti-inflammatory side-effect of the antibiotic employed is unclear. It would have been of great clinical value to verify whether certain cases of the degenerated discs were indeed infected.

Table 2 details all the studies related to DDD for which microscopic evidence is available and that meets our inclusion and exclusion criteria [i.e., (1) disc tissue that was formalin-fixed paraffin-embedded [FFPE] or cryopreserved; (2) a process that included harsh washing steps during sample preparation; (3) tissue sectioning; (4) use of $P$. acnesspecific FISH probes or antibodies].

In the first of two articles describing the visualization of P. acnes in DDD (see Figs. 3 and 4), the authors cultured bacteria from 162 (44\%) of 368 disc specimens obtained during primary disc surgery for symptomatic disc herniations; of these, P. acnes was cultured from 119 (32\%) [15]. Bacterial burden was assessed by determining the number of colony-forming units per gram of tissue. Isolates were subjected to rapid multiplex PCR phylotyping, and phylogroups $\mathrm{IA}_{1}$, IB, IC and II were observed. Eight culturepositive specimens were investigated using FISH, and $P$.

Table 2 DDD original papers where tissue specimen was retrieved from first-time original surgeries/procedures and $P$. acnes biofilm found could not be explained by contamination

\begin{tabular}{|c|c|c|c|}
\hline References & Title of publication & Publication reference & $\begin{array}{l}\text { Microscopic } \\
\text { methodology }\end{array}$ \\
\hline Capoor et al. [15] & $\begin{array}{l}\text { Propionibacterium acnes biofilm is present in intervertebral discs of patients } \\
\text { undergoing microdiscectomy }\end{array}$ & Figure 3 & FISH-CLSM \\
\hline Ohrt-Nissen et al. [24] & $\begin{array}{l}\text { Bacterial biofilms: a possible mechanism for chronic infection in patients with } \\
\text { lumbar disc herniation-a prospective proof-of-concept study using fluores- } \\
\text { cence in situ hybridization }\end{array}$ & Figures 2, 3, 4 & FISH-CLSM \\
\hline
\end{tabular}

Fig. 3 FISH visualization of a $P$. acnes biofilm in disc tissue. a This color-combined image shows a "pocket" of green fluorescent $P$. acnes cells (biofilm) near the center right of the image. Red fluorescence from a general eubacterial probe (b) and green fluorescence from a $P$. acnes-specific probe (c). The $\mathbf{b} / \mathbf{c}$ image is a zoom of a showing fluorescence from the red and green channels separately. Almost all of the cells in a are emitting both red and green fluorescence, indicating that they are P. acnes. (Reprinted from Fig. 3, Capoor et al. [15])
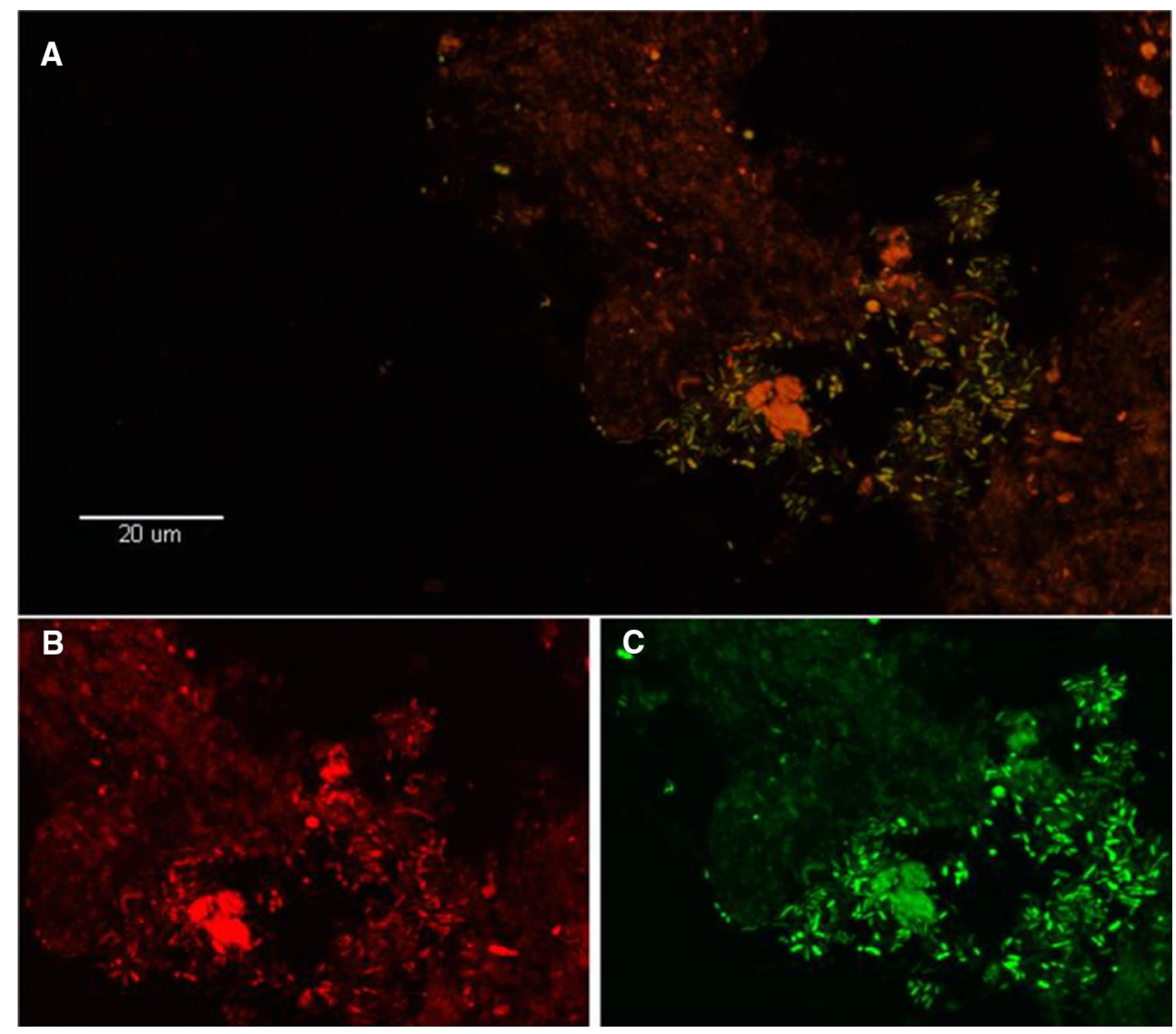
Fig. 4 Visualization of bacterial biofilm in disc tissue. a Threedimensional reconstructed confocal scanning laser microscopy image of $P$. acnes biofilm bacteria in a disc tissue sample (DNA stain SYTO9; green). b, c. The presence of $P$. acnes biofilms in this sample verified using fluorescence in situ hybridization (FISH). Epifluorescence micrographs of a biofilm cluster showing red fluorescence from the CY5-labeled EUB338 general eubacterial probe (b) and green fluorescence from a CY3-labled P. acnes-specific probe (c). Co-localization of the red and green fluorescence indicates that all of the bacteria in this biofilm were $P$. acnes. (Reprinted from Fig. 2, Capoor et al. [15])
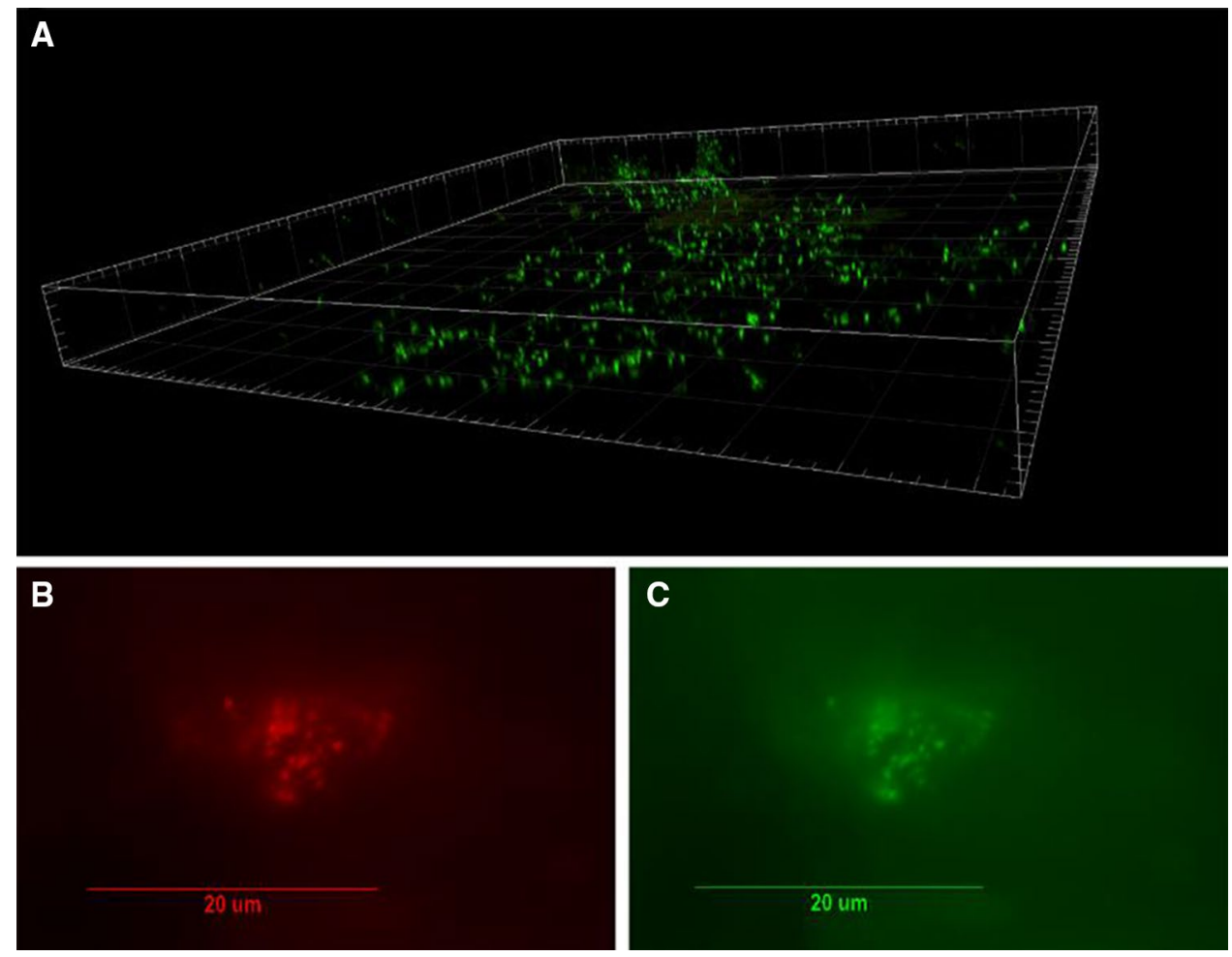

acnes biofilms were observed in $7 / 8$ specimens. Interestingly, infected patients were younger and more often male. This work led to the conclusion that a subset of herniated intervertebral discs are populated with $P$. acnes prior to any surgical procedure or intervention, and not, therefore, the result of contamination.

In the second of two articles describing the visualization of P. acnes in DDD (see Fig. 5), the authors sampled disc tissue from 51 patients surgically treated for a lumbar disc herniation, as well as 14 controls undergoing surgery for non-degenerative disease (most frequently fractures) [24]. As FISH-CLSM may, on rare occasions, produce artifacts that can resemble biofilms the authors imposed strict criteria for the classification of biofilm. These were (1) bacteria are organized in one or more aggregates, not as individual cells and should be embedded at least $2 \mu \mathrm{m}$ within the tissue; (2) inflammatory cells are present in the tissue indicating a host immune response. Bacterial DNA was detected in 16/51 samples in the case group and 7/14 controls. FISH-CLSM demonstrated biofilm in 7/51 LDH patients and no controls. Interestingly, only one of these samples was PCR-positive for bacterial DNA. Furthermore, only $2 / 7$ biofilm samples hybridized to the $P$. acnes probe. The strict biofilm-criteria used in the study are bound to produce false-negatives from the FISH-CLSM, as only a very small part of the disc is being examined. As such, the absolute numbers of positive samples are of little value. The main finding is that bacterial biofilms (including $P$. acnes) were clearly visualized, which supports the theory that a chronic bacterial infection may be closely associated with the development of some cases of DDD.

\section{Acne vulgaris}

Acne vulgaris, known widely as acne, is a chronic inflammatory skin disease seen primarily on the face, neck, chest and back. While $P$. acnes is widely known for its association with this condition, its exact role in the pathophysiology of the disease is still unclear and controversial [44]. Currently, the standard view of acne is that androgen-induced hyperseborrhea and hyperkeratosis are thought to cause changes in the pilosebaceous unit that favor proliferation and dysbiosis of the $P$. acnes population [45, 46]. Androgen levels during puberty are increased which in turn activate sebaceous glands to produce more sebum which, along with hyperkeratinization, leads to clogging of the sebaceous duct and thus comedo formation. While the healthy sebaceous follicle appears to be colonized with a mixture of different $P$. acnes types, the microenvironment of the comedo, which is anaerobic with high lipid content, may possibly provide a growth advantage for "acneic strains from the type $\mathrm{IA}_{1}$ and IC phylogroups which subsequently flourish; strains from these phylogroups have been strongly associated with acne based on both metagenomics and culture-based studies [47]. 

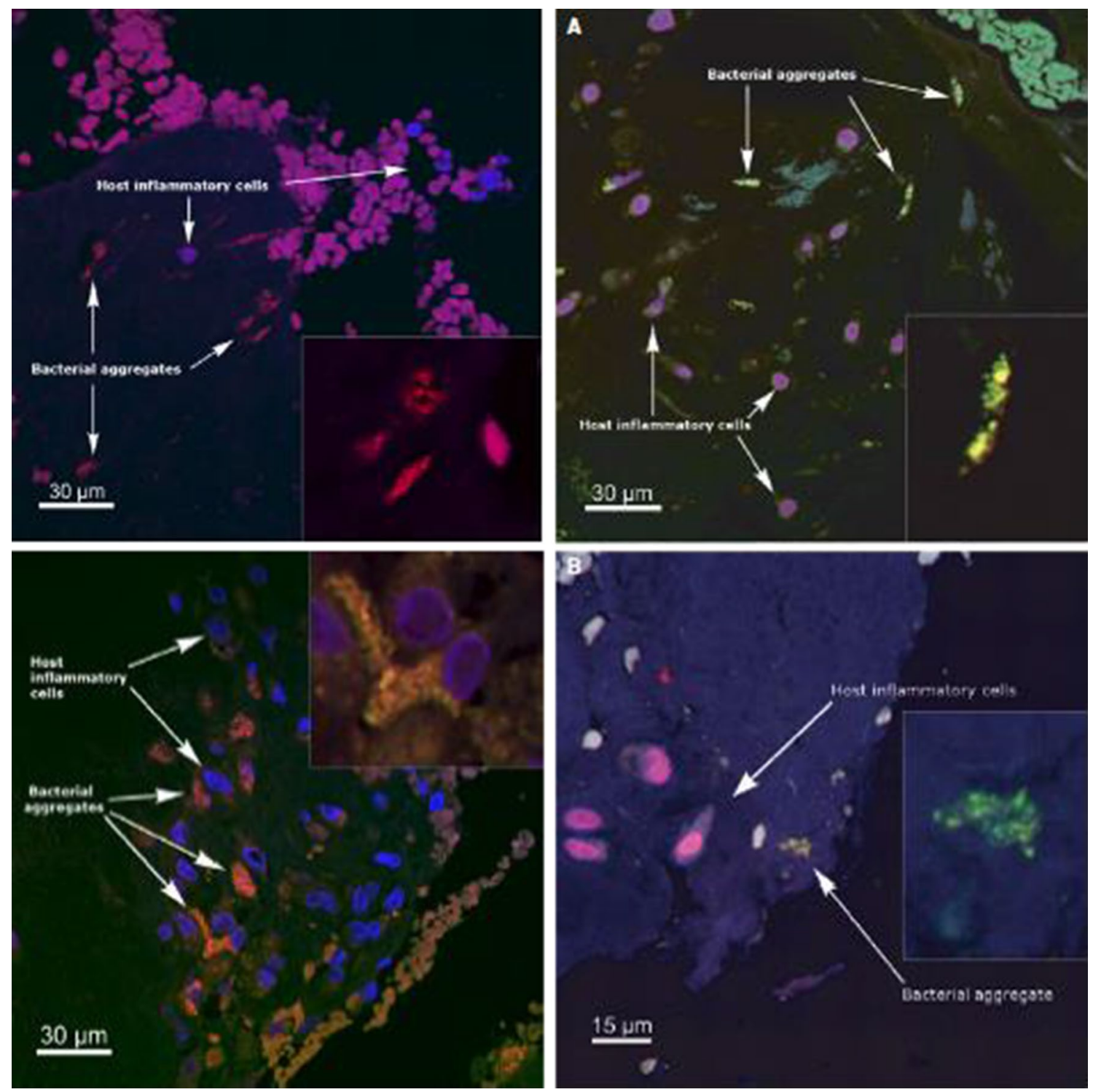

Fig. 5 FISH of herniation samples, with bacterial aggregates hybridized to a universal bacterial probe (left) and a $P$. acnes probe (right, green color). (Reprinted from Figs. 2, 3, 4 of Ohrt-Nissen et al. [24])

Table 3 details the studies related to acne vulgaris for which microscopic evidence is available for a role in the condition, and that meets our inclusion and exclusion criteria described above (paragraph preceding Table 2).

Jahns et al. [19] investigated the occurrence, localization and phylogroup of $P$. acnes in facial biopsies from 38 acne patients versus matched control biopsy samples obtained from patients undergoing benign nevus incision. To visualize $P$. acnes, they used an IFM protocol (with CLSM) with polyclonal and monoclonal (QUBPa3) antibodies targeting $P$. acnes, and monoclonal antibodies (QUBPa1; QUBPa2) that reacted with $P$. acnes type IA, type IC and type II. P. acnes was visualized in the sebaceous follicles of $48 \%$ patient's samples versus $21 \%$ of the control samples, $(p=0.017)$. The
P. acnes in the sebaceous units was found as either microcolonies of $<100$ cells, some of which were attached to the hair shaft, or in extensive biofilms that penetrated deep into the sebaceous follicle. Biofilm was seen in 14 acne samples (37\%) compared to five (13\%) control samples.

Alexeyev et al. [20] and colleagues developed this previous investigation and determined the relative localization of $P$. acnes biofilm and CD3-positive inflammatory cells in the skin of 38 acne patients (median age 19 years) and 19 healthy subjects (median age 28 years). Within the patient group, eight comedones and 32 inflammatory lesions were analyzed. Facial punch biopsies were examined by IFM using the P. acnes monoclonal antibody QUBPa3, and via FISH using probes directed toward 23S rRNA and a 
Table 3 Acne vulgaris original papers where tissue specimens were retrieved from first-time original surgeries/procedures and $P$. acnes biofilm found could not be explained by contamination

\begin{tabular}{|c|c|c|c|}
\hline References & Title of publication & $\begin{array}{l}\text { Publica- } \\
\text { tion refer- } \\
\text { ence }\end{array}$ & Microscopic methodology \\
\hline Jahns et al. [19] & $\begin{array}{l}\text { An increased incidence of Propionibacterium acnes biofilms in acne vulgaris: a } \\
\text { case-control study }\end{array}$ & Figure 5 & IF-CLSM \\
\hline Alexeyev et al. [20] & Pattern of tissue invasion by Propionibacterium acnes in acne vulgaris & Figure 1 & IHC, FISH and IF-CLSM \\
\hline Jahns et al. [21] & $\begin{array}{l}\text { Simultaneous visualization of Propionibacterium acnes and Propionibacterium } \\
\text { granulosum with immunofluorescence and fluorescence in situ hybridization }\end{array}$ & Figure 3 & FISH and IF-CLSM \\
\hline Jahns et al. [22] & $\begin{array}{l}\text { Propionibacterium species and follicular keratinocyte activation in acneic and } \\
\text { normal skin }\end{array}$ & Figure 1 & IHC AND IF-CLSM \\
\hline
\end{tabular}

putative lipase gene. IFM results demonstrated 18 patients (47\%) positive for P. acnes compared to two controls (10\%) $(p=0.0077)$. On the outer layer of the stratum corneum, $P$. acnes was found as isolated cells; however, within the stratum corneum $P$. acnes typically presented as microcolonies were sometimes matrix-encased. In the hair follicle, $P$. acnes were seen as microcolonies ( $>50$ bacteria) and macrocolonies ( $>1000$ bacteria). Finding large matrix-encased macrocolonies attached to the wall of the follicle was clear evidence of $P$. acnes colonization of the follicle. $P$. acnes macrocolonies/biofilm was found in $70 \%$ of colonized acne patients and $16 \%$ of comedones.

In Jahns et al. [21], a proof-of-concept study using a set of FISH and IF assays that allows simultaneous visualization of $P$. acnes and $P$. granulosum in skin biopsy samples was presented. The authors tested their IF assay on samples from six patients with acne vulgaris and two patients with benign nevus. Of the acne vulgaris patients, four patients tested positive for $P$. acnes, one of which also tested positive for $P$. granulosum. One of the samples revealed a combined biofilm of $P$. acnes and $P$. granulosum and the two organisms formed distinct populations. In a study from the same group, Jahns et al. [22] examined the distribution of $P$. acnes, $P$. granulosum and $P$. avidum in acneic and healthy skin by IFM and polyclonal antibodies targeting the cutaneous propionibacteria and found that $P$. acnes was the most common bacterial species in both control and acne samples, and about half of all colonized subjects showed evidence of biofilm in their hair follicles.

\section{Atherosclerosis}

Atherosclerosis is the major underlying cause of ischemia (restriction of the blood), leading to obstruction of peripheral arteries, congestive heart failure, heart attack and stroke. It is currently accepted that atherosclerosis is a gradual multifactorial process that occurs when low-density lipoprotein (LDL) and cholesterol from plasma collect beneath the endothelium (inner lining) of arterial walls following injury to the arterial lining. No consensus exists to indicate the prime cause of damage to the endothelial layer, but risk factors such as high blood pressure, diet, tobacco use, obesity and family history have been positively correlated with atherogenesis. The principal treatments for patients with atherosclerosis center around the reduction of LDL cholesterol in the blood, which is understood to be the principal determinant in the development of stenosis, or narrowing of the arteries, potentially leading to clot formation or rupture and blockage of blood flow to the heart or brain. Emerging research indicates that LDL cholesterol alone may not be responsible for atherosclerosis and, instead, there is strong evidence that other factors including inflammation and possible infection of the artery wall may play key roles in the onset and progression of arterial plaque deposition. Indeed, mounting evidence in the literature points to the regular involvement of bacteria within arterial plaque deposits including Chlamydia pneumonia and various Streptococcus and Staphylococcus species [48-52]. Furthermore, acute bacterial infections, especially of the respiratory system, have been demonstrated to often precede the onset of symptoms of stroke or myocardial infarction by several weeks. For instance, a strong, significant association between infections with a common pathogen of the upper respiratory tract, and cardiovascular disease has been shown [53].

Table 4 details the singular study related to atherosclerosis for which microscopic evidence is available and that meets our inclusion and exclusion criteria described above (paragraph preceding Table 2).

To date, we identified one study where $P$. acnes was found within the atherosclerotic arterial wall and could not be explained by contamination [23]. In this work, diseased human carotid arteries from 15 patients with advanced atherosclerosis were screened for the presence of Propionibacterium $16 \mathrm{~S}$ rRNA, and an additional 10 arteries examined for $P$. acnes after culture in reinforced clostridial medium. DNA sequencing revealed 16s rDNA signatures of $P$. acnes in four samples, and nine samples were found to harbor a 
Table 4 Atherosclerosis paper where tissue specimen was retrieved from first-time original surgeries/procedures and $P$. acnes biofilm found could not be explained by contamination

\begin{tabular}{llll}
\hline References & Title of publication & Publication reference & Microscopic methodology \\
\hline Lanter et al. [23] & $\begin{array}{l}\text { Propionibacterium acnes recovered from atherosclerotic human carotid } \\
\text { arteries undergoes biofilm dispersion and releases lipolytic and proteo- } \\
\text { lytic enzymes in response to norepinephrine challenge in vitro }\end{array}$ & Figure 3a & FISH-CLSM \\
\hline
\end{tabular}

total of at least one or more species of cultivable bacteria, with 11 different species represented; in four of these cases, $P$. acnes was recovered. FISH was also performed on atherosclerotic carotid arteries from five additional patients to visualize the location of $P$. acnes within the plaque deposits, and to assess the relative contribution of $P$. acnes to the overall biofilm load within these infections. Detection of 16S rRNA targets was carried out using fluorescent-labeled peptide-nucleic acid probes (PNA-FISH) for total eubacteria and for $P$. acnes sequences in situ within $25 \mu \mathrm{m}$ sections of carotid arterial plaque samples. Of the five arterial samples analyzed, all showed the presence of biofilm bacteria and four were positive for the presence of $P$. acnes. Bound probe was present throughout the $25 \mu \mathrm{m}$ thickness of the tissue for all five samples analyzed and not solely on the surface, indicating the bacterial biofilms were attached and embedded throughout the tissue.

The four patient carotid artery samples that were positive for $P$. acnes demonstrated the location of eubacterial probe targets with green fluorescence and the location of $P$. acnes-specific $23 \mathrm{~S}$ rRNA probe targets with red fluorescence. Each of the carotid arterial samples was found to be negative for the presence of bound nonsense-eubacterial 16S-rDNA probe. The four samples that were positive for $P$. acnes demonstrated that the probe locations aligned with other bacterial signatures in the sample, indicating a mixed biofilm. These findings showed that $P$. acnes was present and extensively involved within infecting biofilms in 4/5 atherosclerotic carotid arteries, that its involvement was typically associated with damaged tissue, and that it could be located throughout the media and into the adventitia. These observations also demonstrated that $P$. acnes was often associated with other unidentified eubacteria in polymicrobial biofilms.

\section{Prostate cancer}

An association between $P$. acnes colonization/infection of the prostate and malignancy was first proposed in 2005 based on microbiologic culture results from radical prostatectomy specimens of patients with prostate cancer [54]. Bacterial growth was noted in $19 / 34$ specimens (56\%), with $P$. acnes as the most frequently encountered species (observed from 15 patients). In subsequent years, other investigations have detected $P$. acnes, using a variety of experimental methods, from both prostatectomy specimens and biopsies of prostate tumors. These methods include: microbiologic culture [55, 56], P. acnes-targeted PCR [57, 58], pan-eubacterial 16s rDNA PCR with sequencing [57, 59] and non-targeted deep sequencing [60]. Across these studies, the detectable prevalence of $P$. acnes within tumor specimens has ranged significantly from $\sim 23 \%$ to $>90 \%$ $[55,59]$, with other diverse bacterial species variably detected.

Perhaps the most convincing evidence for the presence of $P$. acnes within prostate tumors involves direct histologic observation. Visualization of the organisms in situ, with a defined topological/architectural relationship to the host tissue, rebuts the claim that $P$. acnes is an experimental contaminant. To date, several studies have utilized fluorescence microscopy in combination with organismspecific oligonucleotide probes or antibodies for the detection of $P$. acnes in prostate tissue.

Table 5 details the three studies related to prostate cancer for which microscopic evidence is available and that meets our inclusion and exclusion criteria described above (paragraph preceding Table 2).

Table 5 Prostate cancer original papers where tissue specimen was retrieved from first-time original surgeries/procedures and P. acnes biofilm found could not be explained by contamination

\begin{tabular}{llcc}
\hline References & Title of publication & $\begin{array}{l}\text { Publication refer- } \\
\text { ence }\end{array}$ & $\begin{array}{l}\text { Microscopic } \\
\text { methodology }\end{array}$ \\
\hline Alexeyev et al. [27] & $\begin{array}{l}\text { Direct visualization of P. acnes in prostate tissue by multicolor FISH } \\
\text { Fassi Fehri et al. [25] }\end{array}$ & $\begin{array}{c}\text { Prevalence of Propionibacterium acnes in diseased prostates and its inflam- } \\
\text { matory and transforming activity on prostate epithelial cells }\end{array}$ & Figure 1 \\
Kakegawa et al. [26] & $\begin{array}{l}\text { Frequency of Propionibacterium acnes infection in prostate glands with } \\
\text { negative biopsy results is an independent risk factor for prostate cancer in } \\
\text { patients with increased serum PSA titers }\end{array}$ & Figure 2 & IF-CLSM \\
& IHC & \\
\hline
\end{tabular}


Alexeyev et al. [27] described the visualization of $P$. acnes in diseased prostate tissue using a multicolor FISH assay that targeted $P$. acnes $23 \mathrm{~S}$ rRNA. Using this assay, they demonstrated $P$. acnes infection of the prostate in $5 / 10$ randomly selected prostate cancer patients, and sequential analysis suggested $P$. acnes infection can persist for up to six years. CSLM revealed intracellular localization and stromal biofilm-like aggregates as common forms of $P$. acnes infection in prostate tissues from both prostate cancer and BPH patients. Furthermore, in vitro infection studies with a prostate epithelial cell line revealed that type IB prostate isolate of $P$. acnes could form a biofilm-like conglomerate on the cells. The authors concluded that further study is needed to clarify the clear association between P. acnes, prostatic inflammation and the development of BPH and prostate cancer.

Studies by Fassi Fehri et al. [25] used in situ immunofluorescence and a polyclonal anti-P. acnes antibody to detect the bacterium in 58/71 cancerous prostate tissue specimens. The bacterium was not, however, present in 20 healthy prostates and 59 other cancerous tissue biopsies (mammary carcinoma). The bacterial load in each sample varied widely from a few cells to a large collection found almost exclusively in the secretory epithelium.

A more recent study by Kakegawa et al. [26] investigated the intracellular presence of $P$. acnes in longitudinal needle prostate biopsy specimens of patients with elevated prostate specific antigen (PSA) values. Detection was based on IHC and using a monoclonal antibody specific for $P$. acnes type I and II. The authors compared the presence of $P$. acnes in prostate tissue from 44 patients whose first biopsy specimens were cancer-negative, but ultimately progressed to cancer-positive, with 36 control patients whose biopsies remained cancer-negative throughout the course of the study. Although the number of $P$. acnes-positive macrophages did not differ between the groups, the percent gland-positivity was significantly higher in patients with cancer progression. Most notably, gland-positivity was higher both before the cancer diagnosis (i.e., at the initial negative biopsy $12.1 \%$ vs. $4.8 \%$ ) and at the final biopsy (19.1\% vs. $4.7 \%)$. These results suggest that the frequency of $P$. acnes-positive glands in the first negative prostate biopsy performed due to increased PSA titers can provide valuable clinical information for further biopsy or follow-up strategies.

\section{Discussion}

The studies presented in this review demonstrate the utility of FISH-CLSM, IF-CLSM and IHC in demonstrating the presence of $P$. acnes in diseased human tissue. Given the depth of the bacteria/biofilms within the tissues and the harsh washing steps inherent in these techniques, we are convinced that these findings represent true infection/ colonization, and not instances of contamination. While the microscopy findings that implicate $P$. acnes in acne vulgaris may not be a surprise, similar findings in DDD, prostate disease and atherosclerosis support the emerging recognition of $P$. acnes as an opportunistic pathogen in other human diseases. Although association does not imply causation, it at least provides an initial platform for further evidence-based studies. Of particular relevance are the findings related to DDD since spine-related degeneration and its symptomatology are leading causes of disability worldwide; thus, treatments that prevent degeneration in even a portion of those affected would have a significant effect on the global population. Disc degeneration proceeds along a cascade that has been well defined using histopathological and radiological studies. The process of spine-related degeneration, which is thought to be multifactorial, has attracted a great deal of interest and research. While progress has been made, the search for all causative factors remains active. Well-established contributors to spine-related degeneration include biomechanical factors, changes in disc architecture with aging, traumatic factors and a genetic component; many of these are irreversible, making treatment algorithms for the prevention of disc degeneration based on such factors impractical. However, the identification of potentially reversible or treatable factors that affect the degenerative process represents tangible new directions in the search for expanded treatment options.

Propionibacterium acnes infection represents a new and compelling mechanism of disc degeneration that offers both a potential means of diagnosis and readily available treatment options. Early data support the presence of $P$. acnes within pathological disc material in patients with severe disc conditions requiring surgical treatment [24, 61]. It is important to define the role of $P$. acnes in the context of such discs, and to determine how the infection affects the degenerative process. Identification of $P$. acnes in degenerative discs could indicate that it promotes the degenerative process and, consequently, future treatment modalities for symptomatic disc degeneration could include treatment of the $P$. acnes infection. For example, $P$. acnes peptidoglycan has very pronounced stimulatory effects upon the immune system (e.g., Coparvax) and the presence of $P$. acnes as a biofilm within the discs and other tissues would act as a long-term local immune stimulant. A key element for the clinical application of antibacterial treatments is preoperative identification of potentially infected patients. Unfortunately, standard MRI has not been shown to correlate with intraoperative sample results. We encourage future studies to assess whether advanced imaging (e.g., PET-MRI) or biofilm biomarkers may play a role in this regard. Identifying a method for preoperative identification of infected patients will define the potential for antibiotic therapies for patients 
with symptoms of degenerative disc disease, or pathological intervertebral discs.

The role $P$. acnes appears to play in postoperative spinal infections is another important factor. The published literature indicates there may be two somewhat separate situations that we should consider in this context. First, there are low virulent and most frequently non-pyogenic implant infections whose most frequent common denominating symptom is local [62]. These low-grade infections tend to become clinically symptomatic years after the index surgery and might not be placed into context with a biofilm that originally was introduced during the index surgery, even when a culture positive for $P$. acnes is recognized as a real infection. This situation is similar to the one encountered with shoulder arthroplasty or ventriculoperitoneal shunts. Second, in spinal arthrodesis surgeries where the intervertebral disc is entered and the nucleus evacuated for an interbody arthrodesis procedure, resident $P$. acnes potentially contaminates the interbody implant and the fusion mass. This in turn might lead to so-called "failed fusions" and pseudarthrosis, as a recent publication on revision surgeries has suggested [63]. Spine surgeons may find these two quite realistic scenarios and their potential implications unsettling for several reasons. The thought that a hitherto unknown infectious variable with a potentially decisive influence on clinical outcomes might be at play in spinal surgery certainly is troubling. But the fact that we are not yet in a position to reliably test for the presence or absence of this variable makes such knowledge much more complicated. Should we routinely employ antiseptic rinses or topical antibiotics, which have their own risks and side effects, in certain types of spinal surgery? Which procedures should these be? What should be the consequence of a positive culture obtained during the index surgery, and should we routinely take samples for microbiology? Alternatively, do we need to perform a percutaneous disc biopsy prior to any interbody fusion for chronic low back pain in order to prove that $P$. acnes was preexistent in that particular disc and that the consequently higher risk for a suboptimal clinical result (a "failed fusion"), and need for closer postoperative follow-up and monitoring, was a preexistent risk and not imparted by the surgeon? The questions do not end here. The world-wide crisis of antibiotic-resistance prohibits us from prescribing antibiotics without a clear indication and without a precise rationale. Spinal surgery always has potential complications; postoperative spinal infection represents one of the most common and most-feared complication of spinal surgery. In particular, the frequency of postoperative $P$. acnes infections remains a significant problem. It is common to implant metal devices in the course of spinal surgery, and the presence of $P$. acnes in the discs presents a real risk of spinal implant colonization. The resulting postoperative infection can significantly decrease the success of the surgical procedure. The finding of $P$. acnes in disc material can account for the high number of postoperative infections with this organism. Preoperative treatment with specific antibiotics to eliminate this potential preoperative infection or colonization may be required to reduce the number of postoperative infections. Further study is needed to understand the role of $P$. acnes in the pathogenesis of disc degeneration, and to determine if preoperative protocols to address potential infection would reduce the occurrence of surgical complications.

\section{Conclusion}

Our strict study criteria of FISH-CLSM, IF-CLSM and IHC have provided solid evidence of $P$. acnes low-virulence (biofilm) infection in acne vulgaris, DDD, atherosclerosis and prostate cancer in first-time original surgeries. This, together with increasing evidence suggesting the presence of $P$. acnes as a pathogen in a wide range of human inflammatory conditions, suggests it is important for clinicians, surgeons and researchers to study diseases and infections with a suspected link to a $P$. acnes infection "under the microscope."

Tables $6,7,8,9,10$ and 11 classify 83 of the 96 first original cases (86\%) from Table 2 according to 6 disease types [i.e., acne vulgaris (6), atherosclerosis (5), discectomy

Table 6 Review of first-time original procedure research (9/17/97-8/30/18) for Acne vulgaris

\begin{tabular}{|c|c|c|c|c|c|c|c|}
\hline \multicolumn{2}{|l|}{ Study particulars } & \multicolumn{2}{|l|}{ Study design } & \multirow{2}{*}{$\begin{array}{l}\text { P. acnes identified } \\
\text { Condition/procedure }\end{array}$} & \multicolumn{3}{|c|}{ Diagnostic microscopy } \\
\hline Publication date & References & Patient cases & $\begin{array}{l}\text { Prospective } \\
\text { Retrospective }\end{array}$ & & IHC & FISH-CLSM & IF-CLSM \\
\hline 01/01/01 & Tan et al. [64] & 150 & Prospective & Acne vulgaris & & & \\
\hline $02 / 22 / 12$ & Jahns et al. [19] & 38 & Prospective & Acne vulgaris & & & $\bullet$ \\
\hline $12 / 11 / 14$ & Jahns et al. [22] & 143 & Prospective & Acne vulgaris & $\bullet$ & & $\bullet$ \\
\hline 04/19/17 & Lomholt et al. [65] & 23 & Prospective & Acne vulgaris & & & \\
\hline 04/19/12 & Alexeyev et al. [20] & 38 & Retrospective & Acne vulgaris & $\bullet$ & $\bullet$ & $\bullet$ \\
\hline 07/27/13 & Jahns et al. [21] & 8 & Retrospective & Acne vulgaris & & - & - \\
\hline
\end{tabular}


Table 7 Review of first-time original procedure research (9/17/97-8/30/18) for atherosclerosis

\begin{tabular}{|c|c|c|c|c|c|c|c|}
\hline \multicolumn{2}{|l|}{ Study particulars } & \multicolumn{2}{|l|}{ Study design } & \multirow{2}{*}{$\begin{array}{l}\text { P. acnes identified } \\
\text { Condition/procedure }\end{array}$} & \multicolumn{3}{|c|}{ Diagnostic microscopy } \\
\hline Publication date & References & Patient cases & $\begin{array}{l}\text { Prospective } \\
\text { Retrospective }\end{array}$ & & IHC & FISH-CLSM & IF-CLSM \\
\hline 01/01/13 & Renko et al. [66] & 8 & Prospective & Atherosclerosis-Carotid & & & \\
\hline $05 / 15 / 14$ & Armingohar et al. [67] & 77 & Prospective & Atherosclerosis-Carotid & & & \\
\hline $07 / 27 / 15$ & Lanter et al. [23] & 30 & Prospective & Atherosclerosis-Carotid & & $\bullet$ & \\
\hline $04 / 05 / 17$ & Kestler et al. [68] & 2491 & Prospective & Endocarditis & & & \\
\hline $12 / 01 / 05$ & Delahaye et al. [69] & 31 & Retrospective & Endocarditis & & & \\
\hline
\end{tabular}

Table 8 Review of first-time original procedure research (9/17/97-8/30/18) for discectomy

\begin{tabular}{|c|c|c|c|c|c|c|c|}
\hline \multicolumn{2}{|l|}{ Study particulars } & \multicolumn{2}{|l|}{ Study design } & \multirow{2}{*}{$\begin{array}{l}\text { P. acnes identified } \\
\text { Condition/procedure }\end{array}$} & \multicolumn{3}{|c|}{ Diagnostic microscopy } \\
\hline Publication date & References & Patient cases & $\begin{array}{l}\text { Prospective } \\
\text { Retrospective }\end{array}$ & & $\mathrm{IHC}$ & FISH-CLSM & IF-CLSM \\
\hline $04 / 19 / 18$ & Chen et al. [70] & 32 & Prospective & Discectomy-Cervical & & & \\
\hline 07/15/17 & Javanshir et al. [71] & 145 & Prospective & Discectomy-Cervical/Lumbar & & & \\
\hline $12 / 09 / 16$ & Coscia et al. [42] & 87 & Prospective & Discectomy-Cervical/Lumbar & & & \\
\hline 08/18/16 & Capoor et al. [61] & 290 & Prospective & Discectomy-Lumbar & & & \\
\hline $11 / 24 / 16$ & Aghazadeh et al. [72] & 120 & Prospective & Discectomy-Lumbar & & & \\
\hline $10 / 31 / 17$ & Yuan et al. [73] & 76 & Prospective & Discectomy-Lumbar & & & \\
\hline 08/02/05 & McLorinan et al. [29] & 79 & Prospective & Discectomy-Lumbar & & & $\bullet$ \\
\hline 08/28/13 & Rollason et al. [74] & 64 & Prospective & Discectomy-Lumbar & & & \\
\hline $05 / 31 / 17$ & Alamin et al. [75] & 44 & Prospective & Discectomy-Lumbar & & & \\
\hline 04/03/17 & Capoor et al. [15] & 368 & Prospective & Discectomy-Lumbar & & $\bullet$ & \\
\hline 06/23/01 & Stirling et al. [76] & 176 & Prospective & Discectomy-Lumbar & & & \\
\hline 01/10/18 & Lin et al. [77] & 108 & Prospective & Discectomy-Lumbar & & & \\
\hline $10 / 01 / 12$ & Arndt et al. [78] & 83 & Prospective & Discectomy-Lumbar & & & \\
\hline 01/01/02 & Stirling et al. [79] & 62 & Prospective & Discectomy-Lumbar & & & \\
\hline $02 / 10 / 13$ & Albert et al. [41] & 61 & Prospective & Discectomy-Lumbar & & & \\
\hline 06/18/07 & Carricajo et al. [80] & 54 & Prospective & Discectomy-Lumbar & & & \\
\hline 08/01/11 & Agarwal et al. [81] & 52 & Prospective & Discectomy-Lumbar & & & \\
\hline 08/19/15 & Zhou et al. [82] & 46 & Prospective & Discectomy-Lumbar & & & \\
\hline 11/01/06 & Ben-Galim et al. [83] & 30 & Prospective & Discectomy-Lumbar & & & \\
\hline $04 / 27 / 18$ & Ohrt-Nissen et al. [24] & 51 & Prospective & Discectomy-Lumbar & & $\bullet$ & \\
\hline 02/06/17 & Rajasekaran et al. [84] & 22 & Prospective & Discectomy-Unspecified & & & \\
\hline $01 / 27 / 16$ & Rigal et al. [85] & 313 & Prospective & Fusion & & & \\
\hline $08 / 23 / 18$ & Georgy et al. [86] & 48 & Prospective & Fusion & & & \\
\hline $06 / 02 / 11$ & Shiono et al. [87] & 80 & Prospective & Posterior Spinal Deformity & & & \\
\hline $02 / 02 / 13$ & Nandyala and Schwend [88] & 114 & Retrospective & Posterior Spinal Deformity & & & \\
\hline 06/01/12 & Zohoun et al. [89] & 30 & Retrospective & Spondylodiscitis & & & \\
\hline
\end{tabular}

(26), prostate cancer (16), sarcoidosis (15), shoulder arthroscopy/plasty (15)]. These original cases highlight the possibility that colonization may occur through hematogenous spread following some mechanical damage, followed by local inflammation and healing.

Against this context, it would be prudent to establish a biobank of surgical tissue and isolates taken from patients in whom $P$. acnes infection has been identified. Such biobanks would allow for future microscopy-based studies that provide additional confirmatory evidence of the extent of $P$. acnes infection and also facilitate in vitro and in vivo hostmicrobe investigations of DDD.

Looking forward, screening surgical tissue to determine the likelihood of an underlying $P$. acnes infection may 
Table 9 Review of first-time original procedure research (9/17/97-8/30/18) for prostate cancer

\begin{tabular}{|c|c|c|c|c|c|c|c|}
\hline \multicolumn{2}{|l|}{ Study particulars } & \multicolumn{2}{|l|}{ Study design } & \multirow{2}{*}{$\begin{array}{l}\text { P. acnes identified } \\
\text { Condition/procedure }\end{array}$} & \multicolumn{3}{|c|}{ Diagnostic microscopy } \\
\hline Publication date & References & Patient cases & $\begin{array}{l}\text { Prospective } \\
\text { Retrospective }\end{array}$ & & IHC & FISH-CLSM & IF-CLSM \\
\hline 06/01/05 & Cohen et al. [54] & 34 & Prospective & Prostate cancer & & & \\
\hline 08/02/06 & Shannon et al. [90] & 27 & Prospective & Prostate cancer & & & \\
\hline 09/14/07 & Shannon et al. [91] & 21 & Prospective & Prostate cancer & & & \\
\hline $10 / 12 / 10$ & Fassi Fehri et al. [25] & 71 & Prospective & Prostate cancer & & & $\bullet$ \\
\hline $11 / 28 / 12$ & Mak et al. [55] & 30 & Prospective & Prostate cancer & & & \\
\hline 06/09/15 & Chen et al. [92] & 46 & Prospective & Prostate cancer & & & \\
\hline $09 / 16 / 16$ & Olender et al. [93] & 20 & Prospective & Prostate cancer & & & \\
\hline $11 / 09 / 17$ & Bhudia et al. [94] & 18 & Prospective & Prostate cancer & & & \\
\hline 09/29/06 & Alexeyev et al. [95] & 402 & Retrospective & Prostate cancer & & & \\
\hline 07/08/10 & Severi et al. [96] & 809 & Retrospective & Prostate cancer & & & \\
\hline $02 / 28 / 14$ & Bae et al. [31] & 46 & Retrospective & Prostate cancer & $\bullet$ & & $\bullet$ \\
\hline 06/09/16 & Davidsson et al. [56] & 100 & Retrospective & Prostate cancer & & & \\
\hline 01/01/17 & Yow et al. [59] & 10 & Retrospective & Prostate cancer & & & \\
\hline 01/01/17 & Kakegawa et al. [26] & 44 & Retrospective & Prostate cancer & $\bullet$ & & \\
\hline $04 / 25 / 17$ & Cavarretta et al. [60] & 16 & Retrospective & Prostate cancer & & & \\
\hline 09/19/07 & Alexeyev et al. [27] & 10 & Prospective & Prostate cancer/BPH & & $\bullet$ & \\
\hline
\end{tabular}

Table 10 Review of first-time original procedure research (9/17/97-8/30/18) for Sarcoidosis

\begin{tabular}{|c|c|c|c|c|c|c|c|}
\hline \multicolumn{2}{|l|}{ Study particulars } & \multicolumn{2}{|l|}{ Study design } & \multirow{2}{*}{$\begin{array}{l}\text { P. acnes identified } \\
\text { Condition/procedure }\end{array}$} & \multicolumn{3}{|c|}{ Diagnostic microscopy } \\
\hline Publication Date & References & Patient cases & $\begin{array}{l}\text { Prospective } \\
\text { Retrospective }\end{array}$ & & IHC & FISH-CLSM & IF-CLSM \\
\hline 07/07/17 & Asakawa et al. [33] & 107 & Retrospective & Sarcoidosis-Cardiac & $\bullet$ & & \\
\hline $01 / 24 / 15$ & Nishimoto et al. [97] & 9 & Prospective & Sarcoidosis-Face & & & \\
\hline $10 / 04 / 02$ & Yamada et al. [34] & 27 & Retrospective & Sarcoidosis-Multiple Sites & & $\bullet$ & \\
\hline 02/05/18 & Suzuki et al. [35] & 128 & Retrospective & Sarcoidosis-Multiple Sites & $\bullet$ & & \\
\hline $11 / 09 / 17$ & Nagata et al. [37] & 23 & Prospective & Sarcoidosis-Ocular & $\bullet$ & & \\
\hline 06/14/05 & Yasuhara et al. [98] & 6 & Prospective & Sarcoidosis-Ocular & & & \\
\hline 03/07/17 & Goto et al. [36] & 10 & Prospective & Sarcoidosis-Ocular & $\bullet$ & & \\
\hline 05/11/05 & Ishige et al. [99] & 43 & Prospective & Sarcoidosis-Pulmonary & & & \\
\hline $12 / 19 / 12$ & Oswald-Richter et al. [100] & 50 & Prospective & Sarcoidosis-Pulmonary & & & \\
\hline $10 / 01 / 03$ & Hiramatsu et al. [101] & 60 & Prospective & Sarcoidosis-Pulmonary & & & \\
\hline $05 / 18 / 12$ & Negi et al. [38] & 471 & Retrospective & Sarcoidosis-Pulmonary & $\bullet$ & & $\bullet$ \\
\hline $07 / 24 / 15$ & Schupp et al. [102] & 85 & Retrospective & Sarcoidosis-Pulmonary & & & \\
\hline 09/01/08 & Ichikawa et al. [103] & 72 & Retrospective & Sarcoidosis-Pulmonary & & & \\
\hline 01/01/02 & Eishi et al. [104] & 259 & Retrospective & Sarcoidosis-Pulmonary & & & \\
\hline $05 / 12 / 15$ & Zhou et al. [105] & 160 & Retrospective & Sarcoidosis-Pulmonary & & & \\
\hline
\end{tabular}

provide valuable information for downstream patient treatment and management. Given its unusual anatomy, physiology and pathology, disc tissue is uniquely positioned to be at the forefront of such $P$. acnes low-virulence (biofilm) infection studies. The underlying studies highlight that $P$. acnes affects more than disc tissue and assists the spine surgeon in understanding intervertebral $P$. acnes infections are not an isolated phenomenon and underlines the importance of further research. 


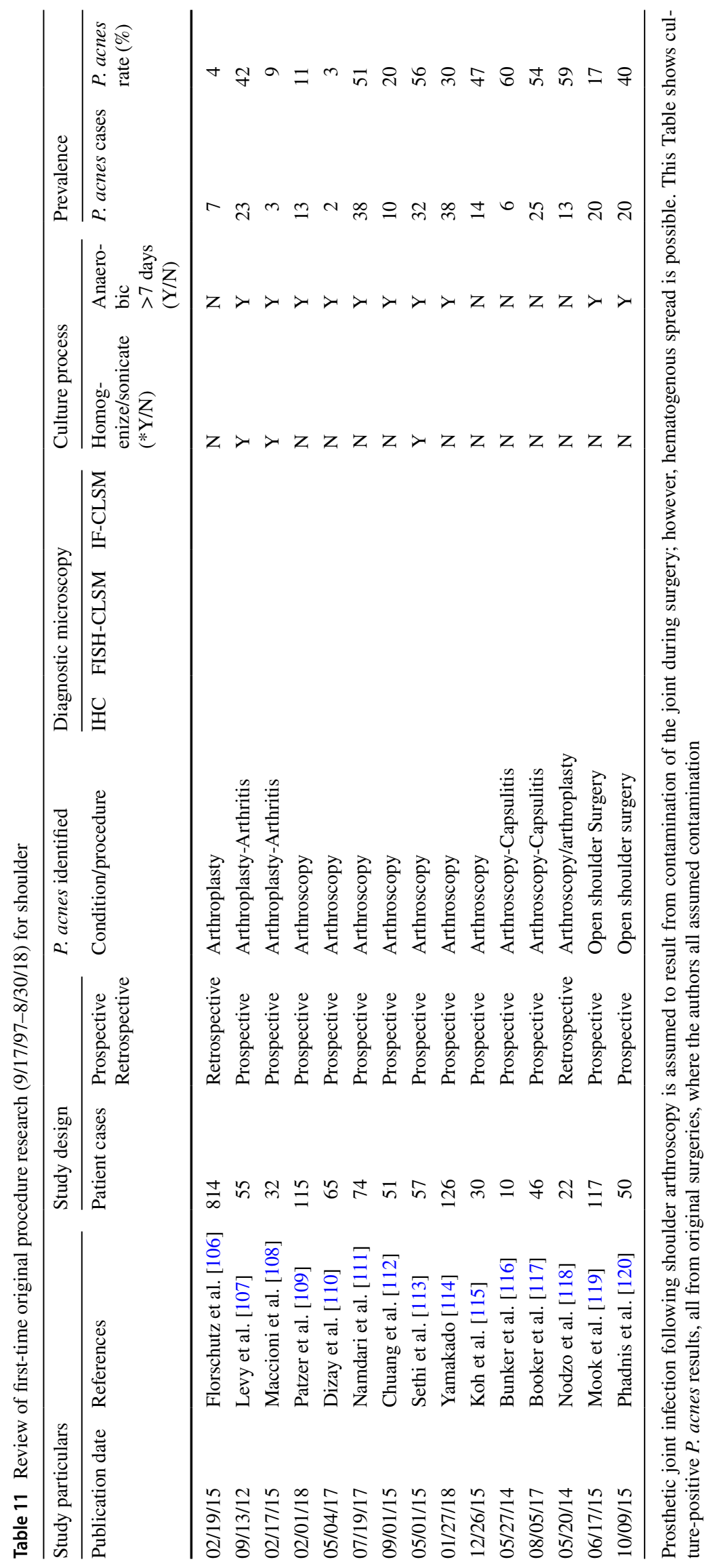


Acknowledgements For historical context, the seminal, potentially paradigm-shifting study first providing evidence linking a $P$. acnes infection of the degenerated disc to CLBP was published by Prof. Peter Lambert and his colleagues in the Lancet (2001). Dr. Lambert detailed his recollection in his July 2, 2017 email to Dr. Capoor how the Lancet publication originated and provided permission to include his email here:

"In terms of the background to our original reason for looking for organisms in disc material, this came about by chance. We had included sera from a group of patients with lower back pain as controls in a study evaluating the value of serological markers in detecting infection by Gram-positive bacteria. We had developed a test that showed some promise in detecting infections of central venous catheters, orthopedic prostheses and prosthetic heart valves. Surprisingly, we found that many of these low back pain "controls" were positive in our serological test and we therefore checked out the possibility of some occult infection of the discs. We cultured disc material and found an unusual number of positive cultures with $P$. acnes. However, the possibility that these culture positives represented contamination of the samples during surgery was always a major concern. The truth is out there somewhere, and it does seem that more people are finding P. acnes and that Koch's postulates on cause and effect are nearly completed."

-Peter A. Lambert, Professor of Microbiology, Aston University.

Funding Not applicable.

\section{Compliance with ethical standards}

Conflict of interest MNC, OS, JES, FR, RJ, MS and CB have stock ownership or options in DiscitisDx, Inc. MNC and OS have filed several patent applications, which have been assigned to DiscitisDx, Inc. JW has investments/options in Bone Biologics Inc., Expanding Orthopedics, Inc., Pearldriver, Inc., Electrocore, Inc., and SurgiTech, Inc. JW receives royalties from Biomet, Inc., Seaspine, Amedica Corp, and Synthes. JW is on the board of directors for North American Spine Society, AO Foundation, Cervical Spine Research Society, Society for Brain Mapping and Therapeutics, and the American Orthopaedic Association. JW is on the editorial boards of Spine, The Spine Journal, Clinical Spine Surgery and Global Spine Journal. JW has fellowship funding (paid to institution) from the AO Foundation.

Open Access This article is distributed under the terms of the Creative Commons Attribution 4.0 International License (http://creativeco mmons.org/licenses/by/4.0/), which permits unrestricted use, distribution, and reproduction in any medium, provided you give appropriate credit to the original author(s) and the source, provide a link to the Creative Commons license, and indicate if changes were made.

\section{References}

1. Vayssier-Taussat M, Albina E, Citti C, Cosson JF, Jacques MA, Lebrun MH, Le Loir Y, Ogliastro M, Petit MA, Roumagnac P, Candresse T (2014) Shifting the paradigm from pathogens to pathobiome: new concepts in the light of meta-omics. Front Cell Infect Microbiol 4:29. https://doi.org/10.3389/fcimb.2014.00029

2. Jahns AC, Eilers H, Alexeyev OA (2016) Transcriptomic analysis of Propionibacterium acnes biofilms in vitro. Anaerobe 42:111118. https://doi.org/10.1016/j.anaerobe.2016.10.001

3. Lee MJ, Pottinger PS, Butler-Wu S, Bumgarner RE, Russ SM, Matsen FA 3rd (2014) Propionibacterium persists in the skin despite standard surgical preparation. J Bone Joint Surg Am 96:1447-1450. https://doi.org/10.2106/JBJS.M.01474
4. Perry A, Lambert P (2011) Propionibacterium acnes: infection beyond the skin. Expert Rev Anti Infect Ther 9:1149-1156. https ://doi.org/10.1586/eri.11.137

5. Bayston R, Ashraf W, Barker-Davies R, Tucker E, Clement R, Clayton J, Freeman BJ, Nuradeen B (2007) Biofilm formation by Propionibacterium acnes on biomaterials in vitro and in vivo: impact on diagnosis and treatment. J Biomed Mater Res A 81:705-709. https://doi.org/10.1002/jbm.a.31145

6. Leal SM Jr, Jones M, Gilligan PH (2016) Clinical significance of commensal Gram-positive rods routinely isolated from patient samples. J Clin Microbiol 54:2928-2936. https://doi. org/10.1128/JCM.01393-16

7. Portillo ME, Corvec S, Borens O, Trampuz A (2013) Propionibacterium acnes: an underestimated pathogen in implantassociated infections. Biomed Res Int 2013:804391. https://doi. org/10.1155/2013/804391

8. Singh JA, Sperling JW, Schleck C, Harmsen W, Cofield RH (2012) Periprosthetic infections after shoulder hemiarthroplasty. J Shoulder Elbow Surg 21:1304-1309. https://doi.org/10.1016/j. jse.2011.08.067

9. Conen A, Walti LN, Merlo A, Fluckiger U, Battegay M, Trampuz A (2008) Characteristics and treatment outcome of cerebrospinal fluid shunt-associated infections in adults: a retrospective analysis over an 11-year period. Clin Infect Dis 47:73-82. https://doi. org/10.1086/588298

10. Rieger UM, Pierer G, Luscher NJ, Trampuz A (2009) Sonication of removed breast implants for improved detection of subclinical infection. Aesthetic Plast Surg 33:404-408. https://doi. org/10.1007/s00266-009-9333-0

11. Wagner L, Braunschweig L, Eiffert H, Tsaknakis K, Kamin D, D'Este E, Messer PK, Hell AK, Lorenz HM (2018) Detection of bacteria colonizing titanium spinal implants in children. Surg Infect (Larchmt) 19:71-77. https://doi.org/10.1089/sur.2017.185

12. Rohacek M, Weisser M, Kobza R, Schoenenberger AW, Pfyffer GE, Frei R, Erne P, Trampuz A (2010) Bacterial colonization and infection of electrophysiological cardiac devices detected with sonication and swab culture. Circulation 121:1691-1697. https ://doi.org/10.1161/CIRCULATIONAHA.109.906461

13. Ramage G, Tunney MM, Patrick S, Gorman SP, Nixon JR (2003) Formation of Propionibacterium acnes biofilms on orthopaedic biomaterials and their susceptibility to antimicrobials. Biomaterials 24:3221-3227

14. Nakatsuji T, Liu YT, Huang CP, Zouboulis CC, Gallo RL, Huang CM (2008) Vaccination targeting a surface sialidase of P. acnes: implication for new treatment of acne vulgaris. PLoS ONE 3:e1551. https://doi.org/10.1371/journal.pone.0001551

15. Capoor MN, Ruzicka F, Schmitz JE, James GA, Machackova T, Jancalek R, Smrcka M, Lipina R, Ahmed FS, Alamin TF, Anand N, Baird JC, Bhatia N, Demir-Deviren S, Eastlack RK, Fisher S, Garfin SR, Gogia JS, Gokaslan ZL, Kuo CC, Lee YP, Mavrommatis K, Michu E, Noskova H, Raz A, Sana J, Shamie AN, Stewart PS, Stonemetz JL, Wang JC, Witham TF, Coscia MF, Birkenmaier C, Fischetti VA, Slaby O (2017) Propionibacterium acnes biofilm is present in intervertebral discs of patients undergoing microdiscectomy. PLoS ONE 12:e0174518. https:// doi.org/10.1371/journal.pone.0174518

16. Tunney MM, Patrick S, Curran MD, Ramage G, Hanna D, Nixon JR, Gorman SP, Davis RI, Anderson N (1999) Detection of prosthetic hip infection at revision arthroplasty by immunofluorescence microscopy and PCR amplification of the bacterial 16S rRNA gene. J Clin Microbiol 37:3281-3290

17. Kvich L, Jensen PO, Justesen US, Bjarnsholt T (2016) Incidence of Propionibacterium acnes in initially culture-negative thioglycollate broths-a prospective cohort study at a Danish University Hospital. Clin Microbiol Infect 22:941-945. https://doi. org/10.1016/j.cmi.2016.07.036 
18. Patrick S, McDowell A (2013) Propionibacterium acnes: an emerging pathogen in biomateria-associated infection. In: Moriarty $\mathrm{T}$, Zaat $\mathrm{S}$, Busscher $\mathrm{H}$ (eds) Biomaterials associated infection. Springer, New York

19. Jahns AC, Lundskog B, Ganceviciene R, Palmer RH, Golovleva I, Zouboulis CC, McDowell A, Patrick S, Alexeyev OA (2012) An increased incidence of Propionibacterium acnes biofilms in acne vulgaris: a case-control study. Br J Dermatol 167:50-58. https://doi.org/10.1111/j.1365-2133.2012.10897.x

20. Alexeyev OA, Lundskog B, Ganceviciene R, Palmer RH, McDowell A, Patrick S, Zouboulis C, Golovleva I (2012) Pattern of tissue invasion by Propionibacterium acnes in acne vulgaris. J Dermatol Sci 67:63-66. https://doi.org/10.1016/j.jderm sci.2012.03.004

21. Jahns AC, Oprica C, Vassilaki I, Golovleva I, Palmer RH, Alexeyev OA (2013) Simultaneous visualization of Propionibacterium acnes and Propionibacterium granulosum with immunofluorescence and fluorescence in situ hybridization. Anaerobe 23:48-54. https://doi.org/10.1016/j.anaerobe.2013.07.002

22. Jahns AC, Eilers H, Ganceviciene R, Alexeyev OA (2015) Propionibacterium species and follicular keratinocyte activation in acneic and normal skin. Br J Dermatol 172:981-987. https://doi. org/10.1111/bjd.13436

23. Lanter BB, Davies DG (2015) Propionibacterium acnes recovered from atherosclerotic human carotid arteries undergoes biofilm dispersion and releases lipolytic and proteolytic enzymes in response to norepinephrine challenge in vitro. Infect Immun 83:3960-3971. https://doi.org/10.1128/IAI.00510-15

24. Ohrt-Nissen S, Fritz BG, Walbom J, Kragh KN, Bjarnsholt T, Dahl B, Manniche C (2018) Bacterial biofilms: a possible mechanism for chronic infection in patients with lumbar disc herniation-a prospective proof-of-concept study using fluorescence in situ hybridization. APMIS 126:440-447. https://doi. org/10.1111/apm.12841

25. Fassi Fehri L, Mak TN, Laube B, Brinkmann V, Ogilvie LA, Mollenkopf H, Lein M, Schmidt T, Meyer TF, Bruggemann H (2011) Prevalence of Propionibacterium acnes in diseased prostates and its inflammatory and transforming activity on prostate epithelial cells. Int J Med Microbiol 301:69-78. https://doi. org/10.1016/j.ijmm.2010.08.014

26. Kakegawa T, Bae Y, Ito T, Uchida K, Sekine M, Nakajima Y, Furukawa A, Suzuki Y, Kumagai J, Akashi T, Eishi Y (2017) Frequency of Propionibacterium acnes infection in prostate glands with negative biopsy results is an independent risk factor for prostate cancer in patients with increased serum PSA titers. PLoS ONE 12:e0169984. https://doi.org/10.1371/journ al.pone. 0169984

27. Alexeyev OA, Marklund I, Shannon B, Golovleva I, Olsson J, Andersson C, Eriksson I, Cohen R, Elgh F (2007) Direct visualization of Propionibacterium acnes in prostate tissue by multicolor fluorescent in situ hybridization assay. J Clin Microbiol 45:3721-3728. https://doi.org/10.1128/JCM.01543-07

28. Jahns AC, Alexeyev OA (2016) Microbial colonization of normal skin: direct visualization of 194 skin biopsies. Anaerobe 38:47-49. https://doi.org/10.1016/j.anaerobe.2015.11.011

29. McLorinan GC, Glenn JV, McMullan MG, Patrick S (2005) Propionibacterium acnes wound contamination at the time of spinal surgery. Clin Orthop Relat Res 437:67-73

30. Jahns AC, Killasli H, Nosek D, Lundskog B, Lenngren A, Muratova Z, Emtestam L, Alexeyev OA (2014) Microbiology of hidradenitis suppurativa (acne inversa): a histological study of 27 patients. APMIS 122:804-809. https://doi.org/10.1111/ apm. 12220

31. Bae Y, Ito T, Iida T, Uchida K, Sekine M, Nakajima Y, Kumagai J, Yokoyama T, Kawachi H, Akashi T, Eishi Y (2014)
Intracellular Propionibacterium acnes infection in glandular epithelium and stromal macrophages of the prostate with or without cancer. PLoS ONE 9:e90324. https://doi.org/10.1371/ journal.pone.0090324

32. Boase S, Foreman A, Cleland E, Tan L, Melton-Kreft R, Pant H, Hu FZ, Ehrlich GD, Wormald PJ (2013) The microbiome of chronic rhinosinusitis: culture, molecular diagnostics and biofilm detection. BMC Infect Dis 13:210. https://doi. org/10.1186/1471-2334-13-210

33. Asakawa N, Uchida K, Sakakibara M, Omote K, Noguchi K, Tokuda Y, Kamiya K, Hatanaka KC, Matsuno Y, Yamada S, Asakawa K, Fukasawa Y, Nagai T, Anzai T, Ikeda Y, IshibashiUeda H, Hirota M, Orii M, Akasaka T, Uto K, Shingu Y, Matsui Y, Morimoto SI, Tsutsui H, Eishi Y (2017) Immunohistochemical identification of Propionibacterium acnes in granuloma and inflammatory cells of myocardial tissues obtained from cardiac sarcoidosis patients. PLoS ONE 12:e0179980. https://doi. org/10.1371/journal.pone.0179980

34. Yamada T, Eishi Y, Ikeda S, Ishige I, Suzuki T, Takemura T, Takizawa T, Koike M (2002) In situ localization of Propionibacterium acnes DNA in lymph nodes from sarcoidosis patients by signal amplification with catalysed reporter deposition. J Pathol 198:541-547. https://doi.org/10.1002/path.1243

35. Suzuki Y, Uchida K, Takemura T, Sekine M, Tamura T, Furukawa A, Hebisawa A, Sakakibara Y, Awano N, Amano T, Kobayashi D, Negi M, Kakegawa T, Wada Y, Ito T, Suzuki T, Akashi T, Eishi Y (2018) Propionibacterium acnes-derived insoluble immune complexes in sinus macrophages of lymph nodes affected by sarcoidosis. PLoS ONE 13:e0192408. https://doi. org/10.1371/journal.pone.0192408

36. Goto H, Usui Y, Umazume A, Uchida K, Eishi Y (2017) Propionibacterium acnes as a possible pathogen of granuloma in patients with ocular sarcoidosis. Br J Ophthalmol 101:1510-1513. https ://doi.org/10.1136/bjophthalmol-2016-309248

37. Nagata K, Eishi Y, Uchida K, Yoneda K, Hatanaka H, Yasuhara T, Nagata M, Sotozono C, Kinoshita S (2017) Immunohistochemical detection of Propionibacterium acnes in the retinal granulomas in patients with ocular sarcoidosis. Sci Rep 7:15226. https://doi.org/10.1038/s41598-017-15710-0

38. Negi M, Takemura T, Guzman J, Uchida K, Furukawa A, Suzuki Y, Iida T, Ishige I, Minami J, Yamada T, Kawachi H, Costabel U, Eishi Y (2012) Localization of propionibacterium acnes in granulomas supports a possible etiologic link between sarcoidosis and the bacterium. Mod Pathol 25:1284-1297. https://doi. org/10.1038/modpathol.2012.80

39. Battie MC, Videman T, Parent E (2004) Lumbar disc degeneration: epidemiology and genetic influences. Spine (Phila Pa 1976) 29:2679-2690

40. Gorman KF, Julien C, Moreau A (2012) The genetic epidemiology of idiopathic scoliosis. Eur Spine J 21:1905-1919. https:// doi.org/10.1007/s00586-012-2389-6

41. Albert HB, Lambert P, Rollason J, Sorensen JS, Worthington T, Pedersen MB, Norgaard HS, Vernallis A, Busch F, Manniche C, Elliott T (2013) Does nuclear tissue infected with bacteria following disc herniations lead to Modic changes in the adjacent vertebrae? Eur Spine J 22:690-696. https://doi.org/10.1007/ s00586-013-2674-z

42. Coscia MF, Denys GA, Wack MF (2016) Propionibacterium acnes, coagulase-negative Staphylococcus, and the "biofilm-like" intervertebral disc. Spine (Phila Pa 1976) 41:1860-1865. https:// doi.org/10.1097/brs.0000000000001909

43. Albert HB, Sorensen JS, Christensen BS, Manniche C (2013) Antibiotic treatment in patients with chronic low back pain and vertebral bone edema (Modic type 1 changes): a double-blind 
randomized clinical controlled trial of efficacy. Eur Spine $\mathbf{J}$ 22:697-707. https://doi.org/10.1007/s00586-013-2675-y

44. Achermann Y, Goldstein EJ, Coenye T, Shirtliff ME (2014) Propionibacterium acnes: from commensal to opportunistic biofilmassociated implant pathogen. Clin Microbiol Rev 27:419-440. https://doi.org/10.1128/CMR.00092-13

45. Williams HC, Dellavalle RP, Garner S (2012) Acne vulgaris. Lancet 379:361-372

46. Dreno B, Pecastaings S, Corvec S, Veraldi S, Khammari A, Roques C (2018) Cutibacterium acnes (Propionibacterium acnes) and acne vulgaris: a brief look at the latest updates. $\mathrm{J}$ Eur Acad Dermatol Venereol 32(Suppl 2):5-14. https://doi. org/10.1111/jdv.15043

47. Barnard E, Nagy I, Hunyadkurti J, Patrick S, McDowell A (2015) Multiplex touchdown PCR for rapid typing of the opportunistic pathogen Propionibacterium acnes. J Clin Microbiol 53:11491155. https://doi.org/10.1128/JCM.02460-14

48. Lehtiniemi J, Karhunen PJ, Goebeler S, Nikkari S, Nikkari ST (2005) Identification of different bacterial DNAs in human coronary arteries. Eur J Clin Invest 35:13-16

49. Ott SJ, El Mokhtari NE, Musfeldt M, Hellmig S, Freitag S, Rehman A, Kuhbacher T, Nikolaus S, Namsolleck P, Blaut M, Hampe J, Sahly H, Reinecke A, Haake N, Gunther R, Kruger D, Lins M, Herrmann G, Folsch UR, Simon R, Schreiber S (2006) Detection of diverse bacterial signatures in atherosclerotic lesions of patients with coronary heart disease. Circulation 113:929-937. https://doi.org/10.1161/circulationaha.105.579979

50. Seymour GJ, Ford PJ, Cullinan MP, Leishman S, Yamazaki K (2007) Relationship between periodontal infections and systemic disease. Clin Microbiol Infect 13:3-10

51. Stoodley P, Sauer K, Davies DG, Costerton JW (2002) Biofilms as complex differentiated communities. Annu Rev Microbiol 56:187-209. https://doi.org/10.1146/annurev.micro.56.01230 2.160705

52. Yoshida Y, Suzuki N, Nakano Y, Shibuya K, Ogawa Y, Koga $\mathrm{T}$ (2003) Distribution of Actinobacillus actinomycetemcomitans serotypes and Porphyromonas gingivalis in Japanese adults. Oral Microbiol Immunol 18:135-139

53. Yamashita K, Ouchi K, Shirai M, Gondo T, Nakazawa T, Ito H (1998) Distribution of Chlamydia pneumoniae infection in the atherosclerotic carotid artery. Stroke 29:773-778

54. Cohen RJ, Shannon BA, McNeal JE, Shannon T, Garrett KL (2005) Propionibacterium acnes associated with inflammation in radical prostatectomy specimens: a possible link to cancer evolution? J Urol 173:1969-1974. https://doi.org/10.1097/01. ju.0000158161.15277.78

55. Mak TN, Yu SH, De Marzo AM, Bruggemann H, Sfanos KS (2013) Multilocus sequence typing (MLST) analysis of Propionibacterium acnes isolates from radical prostatectomy specimens. Prostate 73:770-777. https://doi.org/10.1002/pros.22621

56. Davidsson S, Molling P, Rider JR, Unemo M, Karlsson MG, Carlsson J, Andersson SO, Elgh F, Soderquis B, Andren O (2016) Frequency and typing of Propionibacterium acnes in prostate tissue obtained from men with and without prostate cancer. Infect Agent Cancer 11:26. https://doi.org/10.1186/s13027-016-0074-9

57. Sfanos KS, Sauvageot J, Fedor HL, Dick JD, De Marzo AM, Isaacs WB (2008) A molecular analysis of prokaryotic and viral DNA sequences in prostate tissue from patients with prostate cancer indicates the presence of multiple and diverse microorganisms. Prostate 68:306-320. https://doi.org/10.1002/pros.20680

58. Sfanos KS, Isaacs WB (2008) An evaluation of PCR primer sets used for detection of Propionibacterium acnes in prostate tissue samples. Prostate 68:1492-1495. https://doi.org/10.1002/ pros. 20820
59. Yow MA, Tabrizi SN, Severi G, Bolton DM, Pedersen J, Australian Prostate Cancer B, Giles GG, Southey MC (2017) Characterisation of microbial communities within aggressive prostate cancer tissues. Infect Agent Cancer 12:4. https://doi.org/10.1186/ s13027-016-0112-7

60. Cavarretta I, Ferrarese R, Cazzaniga W, Saita D, Luciano R, Ceresola ER, Locatelli I, Visconti L, Lavorgna G, Briganti A, Nebuloni M, Doglioni C, Clementi M, Montorsi F, Canducci F, Salonia A (2017) The microbiome of the prostate tumor microenvironment. Eur Urol 72:625-631. https://doi.org/10.1016/j.eurur o.2017.03.029

61. Capoor MN, Ruzicka F, Machackova T, Jancalek R, Smrcka M, Schmitz JE, Hermanova M, Sana J, Michu E, Baird JC, Ahmed FS, Maca K, Lipina R, Alamin TF, Coscia MF, Stonemetz JL, Witham T, Ehrlich GD, Gokaslan ZL, Mavrommatis K, Birkenmaier C, Fischetti VA, Slaby O (2016) Prevalence of Propionibacterium acnes in intervertebral discs of patients undergoing lumbar microdiscectomy: a prospective cross-sectional study. PLoS ONE 11:e0161676. https://doi.org/10.1371/journ al.pone. 0161676

62. Collins I, Wilson-MacDonald J, Chami G, Burgoyne W, Vinayakam P, Berendt T, Fairbank J (2008) The diagnosis and management of infection following instrumented spinal fusion. Eur Spine J 17:445-450. https://doi.org/10.1007/s00586-007-0559-8

63. Shifflett GD, Bjerke-Kroll BT, Nwachukwu BU, Kueper J, Burket J, Sama AA, Girardi FP, Cammisa FP, Hughes AP (2016) Microbiologic profile of infections in presumed aseptic revision spine surgery. Eur Spine J 25:3902-3907. https://doi.org/10.1007/ s00586-016-4539-8

64. Tan HH, Goh CL, Yeo MG, Tan ML (2001) Antibiotic sensitivity of Propionibacterium acnes isolates from patients with acne vulgaris in a tertiary dermatological referral centre in Singapore. Ann Acad Med Singapore 30:22-25

65. Lomholt HB, Scholz CFP, Bruggemann H, Tettelin H, Kilian M (2017) A comparative study of Cutibacterium (Propionibacterium) acnes clones from acne patients and healthy controls. Anaerobe 47:57-63. https://doi.org/10.1016/j.anaer obe.2017.04.006

66. Renko J, Koskela KA, Lepp PW, Oksala N, Levula M, Lehtimaki T, Solakivi T, Kunnas T, Nikkari S, Nikkari ST (2013) Bacterial DNA signatures in carotid atherosclerosis represent both commensals and pathogens of skin origin. Eur J Dermatol 23:53-58. https://doi.org/10.1684/ejd.2012.1908

67. Armingohar Z, Jorgensen JJ, Kristoffersen AK, Abesha-Belay E, Olsen I (2014) Bacteria and bacterial DNA in atherosclerotic plaque and aneurysmal wall biopsies from patients with and without periodontitis. J Oral Microbiol 6:23408. https://doi. org/10.3402/jom.v6.23408

68. Kestler M, Munoz P, Marin M, Goenaga MA, Idigoras Viedma $\mathrm{P}$, de Alarcon A, Lepe JA, Sousa Regueiro D, Bravo-Ferrer JM, Pajaron M, Costas C, Garcia-Lopez MV, Hidalgo-Tenorio C, Moreno M, Bouza E, Spanish Collaboration on Endocarditis (GAMES) (2017) Endocarditis caused by anaerobic bacteria. Anaerobe 47:33-38. https://doi.org/10.1016/j.anaer obe.2017.04.002

69. Delahaye F, Fol S, Celard M, Vandenesch F, Beaune J, Bozio A, de Gevigney G (2005) Propionibacterium acnes infective endocarditis. Study of 11 cases and review of literature. Arch Mal Coeur Vaiss 98:1212-1218

70. Chen Y, Wang X, Zhang X, Ren H, Huang B, Chen J, Liu J, Shan Z, Zhu Z, Zhao F (2018) Low virulence bacterial infections in cervical intervertebral discs: a prospective case series. Eur Spine J 27:2496-2505. https://doi.org/10.1007/s00586-018-5582-4

71. Javanshir N, Salehpour F, Aghazadeh J, Mirzaei F, Naseri Alavi SA (2017) The distribution of infection with Propionibacterium 
acnes is equal in patients with cervical and lumbar disc herniation. Eur Spine J 26:3135-3140. https://doi.org/10.1007/s0058 6-017-5219-z

72. Aghazadeh J, Salehpour F, Ziaeii E, Javanshir N, Samadi A, Sadeghi J, Mirzaei F, Naseri Alavi SA (2017) Modic changes in the adjacent vertebrae due to disc material infection with Propionibacterium acnes in patients with lumbar disc herniation. Eur Spine J 26:3129-3134. https://doi.org/10.1007/s0058 6-016-4887-4

73. Yuan Y, Chen Y, Zhou Z, Jiao Y, Li C, Zheng Y, Lin Y, Xiao J, Chen Z, Cao P (2018) Association between chronic inflammation and latent infection of Propionibacterium acnes in non-pyogenic degenerated intervertebral discs: a pilot study. Eur Spine J 27:2506-2517. https://doi.org/10.1007/s00586-017-5363-5

74. Rollason J, McDowell A, Albert HB, Barnard E, Worthington T, Hilton AC, Vernallis A, Patrick S, Elliott T, Lambert P (2013) Genotypic and antimicrobial characterisation of Propionibacterium acnes isolates from surgically excised lumbar disc herniations. Biomed Res Int 2013:530382. https://doi. org/10.1155/2013/530382

75. Alamin TF, Munoz M, Zagel A, Ith A, Carragee E, Cheng I, Scuderi G, Budvytiene I, Banei N (2017) Ribosomal PCR assay of excised intervertebral discs from patients undergoing single-level primary lumbar microdiscectomy. Eur Spine J 26:2038-2044. https://doi.org/10.1007/s00586-017-5141-4

76. Stirling A, Worthington T, Rafiq M, Lambert PA, Elliott TS (2001) Association between sciatica and Propionibacterium acnes. Lancet 357:2024-2025. https://doi.org/10.1016/S0140 $-6736(00) 05109-6$

77. Lin Y, Jiao Y, Yuan Y, Zhou Z, Zheng Y, Xiao J, Li C, Chen Z, Cao P (2018) Propionibacterium acnes induces intervertebral disc degeneration by promoting nucleus pulposus cell apoptosis via the TLR2/JNK/mitochondrial-mediated pathway. Emerg Microbes Infect 7:1. https://doi.org/10.1038/s41426-017-0002-0

78. Arndt J, Charles YP, Koebel C, Bogorin I, Steib JP (2012) Bacteriology of degenerated lumbar intervertebral disks. J Spinal Disord Tech 25:E211-E216. https://doi.org/10.1097/BSD.0b013 e318269851a

79. Stirling A, Rafiq M, Mathur K, Elliot TS, Worthington T, Lambert PA (2002) Association between sciatica and skin commensals. J Bone Joint Surg 84-B:147

80. Carricajo A, Nuti C, Aubert E, Hatem O, Fonsale N, Mallaval FO, Vautrin AC, Brunon J, Aubert G (2007) Propionibacterium acnes contamination in lumbar disc surgery. J Hosp Infect 66:275-277. https://doi.org/10.1016/j.jhin.2007.04.007

81. Agarwal V, Golish SR, Alamin TF (2011) Bacteriologic culture of excised intervertebral disc from immunocompetent patients undergoing single level primary lumbar microdiscectomy. J Spinal Disord Tech 24:397-400. https://doi.org/10.1097/BSD.0b013 e3182019f3a

82. Zhou Z, Chen Z, Zheng Y, Cao P, Liang Y, Zhang X, Wu W, Xiao J, Qiu S (2015) Relationship between annular tear and presence of Propionibacterium acnes in lumbar intervertebral disc. Eur Spine J 24:2496-2502. https://doi.org/10.1007/s0058 6-015-4180-y

83. Ben-Galim P, Rand N, Giladi M, Schwartz D, Ashkenazi E, Millgram M, Dekel S, Floman Y (2006) Association between sciatica and microbial infection: true infection or culture contamination? Spine (Phila Pa 1976) 31:2507-2509. https://doi.org/10.1097/01. brs.0000238657.13263.b2

84. Rajasekaran S, Tangavel C, Aiyer SN, Nayagam SM, Raveendran M, Demonte NL, Subbaiah P, Kanna R, Shetty AP, Dharmalingam K (2017) ISSLS PRIZE IN CLINICAL SCIENCE 2017: is infection the possible initiator of disc disease? An insight from proteomic analysis. Eur Spine J 26:1384-1400. https://doi. org/10.1007/s00586-017-4972-3
85. Rigal J, Thelen T, Byrne F, Cogniet A, Boissiere L, Aunoble S, Le Huec JC (2016) Prospective study using anterior approach did not show association between Modic 1 changes and low grade infection in lumbar spine. Eur Spine J 25:1000-1005. https://doi. org/10.1007/s00586-016-4396-5

86. Georgy MM, Vaida F, Stern M, Murphy K (2018) Association between type 1 Modic changes and Propionibacterium acnes infection in the cervical spine: an observational study. AJNR Am J Neuroradiol 39:1764-1767. https://doi.org/10.3174/ajnr.a5741

87. Shiono Y, Watanabe K, Hosogane N, Tsuji T, Ishii K, Nakamura M, Toyama Y, Chiba K, Matsumoto M (2012) Sterility of posterior elements of the spine in posterior correction surgery. Spine (Phila Pa 1976) 37:523-526. https://doi.org/10.1097/brs.0b013 e $318224 d 7 b 2$

88. Nandyala SV, Schwend RM (2013) Prevalence of intraoperative tissue bacterial contamination in posterior pediatric spinal deformity surgery. Spine (Phila Pa 1976) 38:E482-E486. https ://doi.org/10.1097/brs.0b013e3182893be1

89. Zohoun A, Ngoh Akwa E, El Ochi M, Oragwu N, Akhaddar A, Albouzidi A, El Ouennass M (2012) Bacteriological features of infectious spondylodiscitis at Mohammed V Military Teaching Hospital of Rabat. Braz J Microbiol 43:1327-1331. https://doi. org/10.1590/S1517-838220120004000013

90. Shannon BA, Cohen RJ, Garrett KL (2006) Polymerase chain reaction-based identification of Propionibacterium acnes types isolated from the male urinary tract: evaluation of adolescents, normal adults and men with prostatic pathology. BJU Int 98:388392. https://doi.org/10.1111/j.1464-410X.2006.06273.x

91. Shannon BA, Cohen RJ, Garrett KL (2008) The antibody response to Propionibacterium acnes is an independent predictor of serum prostate-specific antigen levels in biopsy-negative men. BJU Int 101:429-435. https://doi.org/10.1111/j.1464410X.2007.07214.X

92. Chen Y, Wei J (2015) Identification of pathogen signatures in prostate cancer using RNA-seq. PLoS ONE 10:e0128955. https ://doi.org/10.1371/journal.pone.0128955

93. Olender A, Radej S, Plaza P, Bar K, Maciejewski R (2016) Propionibacterium acnes infection associated with cancerous prostate hypertrophy. Pol Arch Med Wewn 126:697-699. https://doi. org/10.20452/pamw.3553

94. Bhudia R, Ahmad A, Akpenyi O, Whiley A, Wilks M, Oliver T (2017) Identification of low oxygen-tolerating bacteria in prostate secretions of cancer patients and discussion of possible aetiological significance. Sci Rep 7:15164. https://doi.org/10.1038/ s41598-017-13782-6

95. Alexeyev O, Bergh J, Marklund I, Thellenberg-Karlsson C, Wiklund F, Gronberg H, Bergh A, Elgh F (2006) Association between the presence of bacterial 16S RNA in prostate specimens taken during transurethral resection of prostate and subsequent risk of prostate cancer (Sweden). Cancer Causes Control 17:1127-1133. https://doi.org/10.1007/s10552-006-0054-2

96. Severi G, Shannon BA, Hoang HN, Baglietto L, English DR, Hopper JL, Pedersen J, Southey MC, Sinclair R, Cohen RJ, Giles GG (2010) Plasma concentration of Propionibacterium acnes antibodies and prostate cancer risk: results from an Australian population-based case-control study. Br J Cancer 103:411-415. https://doi.org/10.1038/sj.bjc.6605757

97. Nishimoto J, Amano M, Setoyama M (2015) The detection of Propionibacterium acnes signatures in granulomas of lupus miliaris disseminatus faciei. J Dermatol 42:418-421. https:// doi.org/10.1111/1346-8138.12773

98. Yasuhara T, Tada R, Nakano Y, Tei M, Mochida C, Kamei M, Kinoshita S (2005) The presence of Propionibacterium spp. in the vitreous fluid of uveitis patients with sarcoidosis. Acta Ophthalmol Scand 83:364-369. https://doi.org/10.111 1/j.1600-0420.2005.00449.x 
99. Ishige I, Eishi Y, Takemura T, Kobayashi I, Nakata K, Tanaka I, Nagaoka S, Iwai K, Watanabe K, Takizawa T, Koike M (2005) Propionibacterium acnes is the most common bacterium commensal in peripheral lung tissue and mediastinal lymph nodes from subjects without sarcoidosis. Sarcoidosis Vasc Diffuse Lung Dis 22:33-42

100. Oswald-Richter KA, Beachboard DC, Seeley EH, Abraham S, Shepherd BE, Jenkins CA, Culver DA, Caprioli RM, Drake WP (2012) Dual analysis for mycobacteria and propionibacteria in sarcoidosis BAL. J Clin Immunol 32:1129-1140. https://doi. org/10.1007/s10875-012-9700-5

101. Hiramatsu J, Kataoka M, Nakata Y, Okazaki K, Tada S, Tanimoto M, Eishi Y (2003) Propionibacterium acnes DNA detected in bronchoalveolar lavage cells from patients with sarcoidosis. Sarcoidosis Vasc Diffuse Lung Dis 20:197-203

102. Schupp JC, Tchaptchet S, Lutzen N, Engelhard P, Muller-Quernheim J, Freudenberg MA, Prasse A (2015) Immune response to Propionibacterium acnes in patients with sarcoidosis-in vivo and in vitro. BMC Pulm Med 15:75. https://doi.org/10.1186/ s12890-015-0070-7

103. Ichikawa H, Kataoka M, Hiramatsu J, Ohmori M, Tanimoto Y, Kanehiro A, Nakata Y, Tanimoto M (2008) Quantitative analysis of propionibacterial DNA in bronchoalveolar lavage cells from patients with sarcoidosis. Sarcoidosis Vasc Diffuse Lung Dis 25:15-20

104. Eishi Y, Suga M, Ishige I, Kobayashi D, Yamada T, Takemura T, Takizawa T, Koike M, Kudoh S, Costabel U, Guzman J, Rizzato G, Gambacorta M, du Bois R, Nicholson AG, Sharma OP, Ando M (2002) Quantitative analysis of mycobacterial and propionibacterial DNA in lymph nodes of Japanese and European patients with sarcoidosis. J Clin Microbiol 40:198-204

105. Zhao MM, Du SS, Li QH, Chen T, Qiu H, Wu Q, Chen SS, Zhou Y, Zhang Y, Hu Y, Su YL, Shen L, Zhang F, Weng D, Li HP (2017) High throughput 16SrRNA gene sequencing reveals the correlation between Propionibacterium acnes and sarcoidosis. Respir Res 18:28. https://doi.org/10.1186/s12931-017-0515-z

106. Florschutz AV, Lane PD, Crosby LA (2015) Infection after primary anatomic versus primary reverse total shoulder arthroplasty. J Shoulder Elbow Surg 24:1296-1301. https://doi.org/10.1016/j.jse.2014.12.036

107. Levy O, Iyer S, Atoun E, Peter N, Hous N, Cash D, Musa F, Narvani AA (2013) Propionibacterium acnes: an underestimated etiology in the pathogenesis of osteoarthritis? J Shoulder Elbow Surg 22:505-511. https://doi.org/10.1016/j.jse.2012.07.007

108. Maccioni CB, Woodbridge AB, Balestro JC, Figtree MC, Hudson BJ, Cass B, Young AA (2015) Low rate of Propionibacterium acnes in arthritic shoulders undergoing primary total shoulder replacement surgery using a strict specimen collection technique. J Shoulder Elbow Surg 24:1206-1211. https://doi.org/10.1016/j.jse.2014.12.026

109. Patzer T, Petersdorf S, Krauspe R, Verde PE, Henrich B, Hufeland M (2018) Prevalence of Propionibacterium acnes in the glenohumeral compared with the subacromial space in primary shoulder arthroscopies. J Shoulder Elbow Surg 27:771-776. https ://doi.org/10.1016/j.jse.2017.10.039
110. Dizay HH, Lau DG, Nottage WM (2017) Benzoyl peroxide and clindamycin topical skin preparation decreases Propionibacterium acnes colonization in shoulder arthroscopy. J Shoulder Elbow Surg 26:1190-1195. https://doi.org/10.1016/j. jse.2017.03.003

111. Namdari S, Nicholson T, Parvizi J, Ramsey M (2017) Preoperative doxycycline does not decolonize Propionibacterium acnes from the skin of the shoulder: a randomized controlled trial. J Shoulder Elbow Surg 26:1495-1499. https://doi.org/10.1016/j.jse.2017.06.039

112. Chuang MJ, Jancosko JJ, Mendoza V, Nottage WM (2015) The incidence of Propionibacterium acnes in shoulder arthroscopy. Arthroscopy 31:1702-1707. https://doi.org/10.1016/j.arthr o.2015.01.029

113. Sethi PM, Sabetta JR, Stuek SJ, Horine SV, Vadasdi KB, Greene RT, Cunningham JG, Miller SR (2015) Presence of Propionibacterium acnes in primary shoulder arthroscopy: results of aspiration and tissue cultures. J Shoulder Elbow Surg 24:796-803. https://doi.org/10.1016/j.jse.2014.09.042

114. Yamakado K (2018) Propionibacterium acnes suture contamination in arthroscopic rotator cuff repair: a prospective randomized study. Arthroscopy 34:1151-1155. https://doi.org/10.1016/j.arthr o.2017.10.029

115. Koh CK, Marsh JP, Drinkovic D, Walker CG, Poon PC (2016) Propionibacterium acnes in primary shoulder arthroplasty: rates of colonization, patient risk factors, and efficacy of perioperative prophylaxis. J Shoulder Elbow Surg 25:846-852. https://doi. org/10.1016/j.jse.2015.09.033

116. Bunker TD, Boyd M, Gallacher S, Auckland CR, Kitson J, Smith CD (2014) Association between Propionibacterium acnes and frozen shoulder: a pilot study. Shoulder Elbow 6:257-261. https ://doi.org/10.1177/1758573214533664

117. Booker SJ, Boyd M, Gallacher S, Evans JP, Auckland C, Kitson J, Thomas W, Smith CD (2017) The colonisation of the glenohumeral joint by Propionibacterium acnes is not associated with frozen shoulder but is more likely to occur after an injection into the joint. Bone Joint J 99-B:1067-1072. https://doi. org/10.1302/0301-620x.99b8.bjj-2016-1168.r2

118. Nodzo SR, Hohman DW, Crane JK, Duquin TR (2014) Hemolysis as a clinical marker for Propionibacterium acnes orthopedic infection. Am J Orthop (Belle Mead NJ) 43:E93-E97

119. Mook WR, Klement MR, Green CL, Hazen KC, Garrigues GE (2015) The incidence of Propionibacterium acnes in open shoulder surgery: a controlled diagnostic study. J Bone Joint Surg Am 97:957-963. https://doi.org/10.2106/JBJS.N.00784

120. Phadnis J, Gordon D, Krishnan J, Bain GI (2016) Frequent isolation of Propionibacterium acnes from the shoulder dermis despite skin preparation and prophylactic antibiotics. J Shoulder Elbow Surg 25:304-310. https://doi.org/10.1016/j. jse.2015.08.002

Publisher's Note Springer Nature remains neutral with regard to jurisdictional claims in published maps and institutional affiliations.

\section{Affiliations}

\section{Manu N. Capoor ${ }^{1,5}$ - Christof Birkenmaier ${ }^{2} \cdot$ Jeffrey C. Wang ${ }^{3} \cdot$ Andrew McDowell $^{4} \cdot$ Fahad S. Ahmed $^{5}$. Holger Brüggemann ${ }^{6} \cdot$ Erin Coscia $^{7} \cdot$ David G. Davies $^{8}$. Soren Ohrt-Nissen ${ }^{9} \cdot$ Assaf Raz $^{1} \cdot$ Filip Ruzicka $^{10}$. Jonathan E. Schmitz ${ }^{11}$. Vincent A. Fischetti ${ }^{1}$. Ondrej Slaby ${ }^{5}$}

Manu N. Capoor

mcapoor@mail.rockefeller.edu

Ondrej Slaby

ondrej.slaby@ceitec.muni.cz
Laboratory of Bacterial Pathogenesis and Immunology, Rockefeller University, 1230 York Avenue, New York, NY, USA 
2 Department of Orthopedics, Physical Medicine \& Rehabilitation, University of Munich (LMU), Munich, Germany

3 Department of Orthopedic Surgery, University Southern California, Los Angeles, CA, USA

4 Northern Ireland Centre for Stratified Medicine, School of Biomedical Sciences, Ulster University, Londonderry, United Kingdom

5 Central European Institute of Technology (CEITEC), Masaryk University, Kamenice 753/5, 62500 Brno, Czech Republic

6 Department of Biomedicine, Aarhus University, Aarhus, Denmark

7 Marian University Osteopathic Medical School, Indianapolis, IN, USA
8 Department of Biological Sciences and Binghamton Biofilm Research Center, Binghamton University, Binghamton, NY, USA

9 Department of Orthopedic Surgery, Spine Unit, Rigshospitalet, University of Copenhagen, Copenhagen, Denmark

10 Department of Microbiology, Faculty of Medicine, St. Anne's University Hospital, Masaryk University, Brno, Czech Republic

11 Department of Pathology, Microbiology and Immunology, School of Medicine, Vanderbilt University, Nashville, TN, USA 